\title{
Copper isotope signatures in modern marine sediments
}

\section{Journal Article}

\section{Author(s):}

Little, Susan H.; Vance, Derek; McManus, James; Severmann, Silke; Lyons, Timothy W.

Publication date:

2017-09-01

Permanent link:

https://doi.org/10.3929/ethz-b-000191704

Rights / license:

Creative Commons Attribution-NonCommercial-NoDerivatives 4.0 International

\section{Originally published in:}

Geochimica et Cosmochimica Acta 212, https://doi.org/10.1016/j.gca.2017.06.019

\section{Funding acknowledgement:}

153087 - Understanding the oceanic cycling of trace metal micronutrients (SNF) 


\section{Copper isotope signatures in modern marine sediments}

Susan H. Little ${ }^{\mathrm{a} *}$, Derek Vance ${ }^{\mathrm{b}}$, James McManus ${ }^{\mathrm{c}}$, Silke Severmann ${ }^{\mathrm{d}}$, Timothy W. Lyons ${ }^{\mathrm{e}}$

*corresponding author: $\quad$ s.little@imperial.ac.uk +44 (0) 2075947358

${ }^{a}$ Department of Earth Science and Engineering, Royal School of Mines, Imperial College London, London SW7 2BP, U.K.

${ }^{\mathrm{b}}$ Institute of Geochemistry and Petrology, Department of Earth Sciences, ETH Zürich, Clausiusstrasse 25, 8092 Zürich, Switzerland.

${ }^{c}$ Bigelow Laboratory for Ocean Sciences, 60 Bigelow Drive, P.O. Box 380, East Boothbay, Maine 04544, USA.

d Department of Marine and Coastal Science, Rutgers, The State University of New Jersey, New Brunswick, New Jersey 08901-8521, USA.

${ }^{\mathrm{e}}$ Department of Earth Sciences, University of California, Riverside, USA. timothy.lyons@ucr.edu 


\begin{abstract}
The development of metal stable isotopes as tools in paleoceanography requires a thorough understanding of their modern marine cycling. To date, no $\mathrm{Cu}$ isotope data has been published for modern sediments deposited under low oxygen conditions. We present data encompassing a broad spectrum of hydrographic and redox regimes, including continental margin and euxinic (sulphide-containing) settings. Taken together with previously published data from oxic settings, these data indicate that the modern oceanic sink for $\mathrm{Cu}$ has a surprisingly homogeneous isotopic composition of about $+0.3 \%$ o $\left(\delta^{65} \mathrm{Cu}\right.$, relative to NIST SRM 976). We suggest that this signature reflects one of two specific water-column processes: (1) an equilibrium isotope fractionation between soluble, isotopically heavy, $\mathrm{Cu}$ complexed to strong organic ligands and an isotopically light pool sorbed to particles that deliver $\mathrm{Cu}$ to the sediment, or (2) an equilibrium isotope fractionation between the same isotopically heavy ligand-bound pool and the particle reactive free $\mathrm{Cu}^{2+}$ species, with the latter being scavenged by particulates and thereby delivered to the sediment. An output flux of about $+0.3 \%$ into sediments is isotopically light relative to the known inputs to the ocean (at around $+0.6 \%$ ) and the seawater value of +0.6 to $+0.9 \%$, suggesting the presence of an as yet unidentified isotopically light source of $\mathrm{Cu}$ to the oceans. We hypothesize that this source may be hydrothermal, or may result from the partial dissolution of continentally derived particles.
\end{abstract}




\section{Introduction}

2

3 Copper $(\mathrm{Cu})$ is biologically essential, but the free $\mathrm{Cu}^{2+}$ form is also toxic, even at

4 extremely low concentrations (e.g., Moffett and Brand, 1996). Aqueous Cu speciation is,

5 however, almost universally dictated by complexation to strong organic ligands (e.g.,

6 Elderfield, 1981; Coale and Bruland, 1988; Gordon et al., 1996; Skrabal et al., 1997; 2000;

7 Wells et al., 1998; Muller et al., 2001; Laglera and van den Berg, 2003; Shank et al.,

8 2004a; 2004b; Bruland and Lohan, 2003; Moffett and Dupont, 2007). In addition to its

9 biological function, $\mathrm{Cu}$ is particle reactive, and its speciation and solubility are sensitive to changes in redox conditions. Understanding the balance of these competing processes in controlling the oceanic distribution of $\mathrm{Cu}$ and its isotopes has been the subject of a large number of studies (e.g., Boyle et al., 1977; Bruland, 1980; Saager et al., 1992; Bermin et al., 2006; Vance et al., 2008; Thompson et al., 2014; Takano et al., 2014; Little et al., 2014a,b).

Isotopes provide insight into the mechanisms of metal cycling, with specific isotope signatures attributable to particular processes (e.g., Welch et al., 2003; Barling and Anbar, 2004; Severmann et al., 2008; Wasylenki et al., 2011; Peacock and Moon, 2012; Xue et al., 2013; Little et al., 2014b; Vance et al., 2016a). Isotopic measurements are also a useful way to place constraints on oceanic mass balance (e.g., Zhu and Macdougall, 1998; Schmitt et al., 2003; Tipper et al., 2006; 2010; Nielsen et al., 2006; Archer and Vance, 2008; Conway and John, 2014; Little et al., 2014a). Based on an analysis of the known inputs and outputs of $\mathrm{Cu}$ and its isotopes to the modern ocean, Little et al. (2014a) highlighted an imbalance in the oceanic budget of $\mathrm{Cu}$. Assuming that the cycle is in steady state, these authors suggested the presence of an as yet unidentified isotopically heavy $\mathrm{Cu}$ sink (Little et al., 2014a).

No $\mathrm{Cu}$ isotope data exist to date for reducing sedimentary settings, making them a prime candidate for the missing $\mathrm{Cu}$ sink. Reducing depositional environments include locations where the water column is euxinic (sulphide-containing), such as the Black Sea and Cariaco Basin, and those in which dissolved oxygen concentrations are negligible but sulphide is either absent or restricted to pore-waters. The latter are typical of oxygen minimum zones (OMZs) along productive continental margins. Copper is insoluble under 
reducing conditions. Consequently, water column removal of $\mathrm{Cu}$ is nearly quantitative below the redoxcline of the euxinic Black Sea and Cariaco Basin (Jacobs et al., 1987; Haraldsson and Westerlund, 1988; Tankéré et al., 2001), and variable Cu enrichments have previously been observed in reducing sediments (e.g., Francois, 1988; Calvert and Perderson, 1993; Algeo and Maynard, 2004; Brumsack, 2006; Little et al., 2015). An ironrich (ferruginous) pore water profile from the oxygen-poor Santa Monica basin (California) shows evidence of $\mathrm{Cu}$ diffusion into sediments and no detectable $\mathrm{Cu}$ in pore waters within a few centimetres of the sediment-water interface, suggesting diagenetic removal of $\mathrm{Cu}$ into sedimentary sulphide phases (Shaw et al., 1990). Generally, however, there is a lack of similar pore water studies from sediment underlying anoxic ocean waters.

Reduction of $\mathrm{Cu}(\mathrm{II})$ to $\mathrm{Cu}(\mathrm{I})$ is likely to be associated with a light isotope fractionation into the reduced phase (e.g., Zhu et al., 2002; Ehrlich et al., 2004; Fujii et al., 2013, Sherman, 2013), i.e., fractionation in the opposite direction to that required for an isotopically heavy $\mathrm{Cu}$ sink. However, quantitative removal from the water column implies that the authigenic $\mathrm{Cu}$ isotope values of sediments deposited under euxinic conditions should reflect the $\mathrm{Cu}$ isotope composition of the dissolved pool of the oceans, as observed previously for similar metal isotope systems (e.g., Mo, Zn, Cr; Barling et al., 2001; Nägler et al., 2011; Reinhard et al., 2014; Vance et al., 2016a). The dissolved $\mathrm{Cu}$ pool in seawater is, indeed, isotopically heavy, at +0.6 to $+0.9 \%$ (Vance et al., 2008; Thompson et al., 2014; Takano et al., 2014).

Euxinic sites play a relatively minor role as a global sink for trace metals in the modern ocean, however, due to the restricted areal extent of such conditions (e.g., Emerson and Huested, 1991; Morford and Emerson, 1999; Poulson Brucker et al., 2009; Little et al., 2015). Today, upwelling margins with prominent OMZs are likely a much more important sink for trace metals (e.g., Morford and Emerson, 1999; Böning et al., 2004; 2009; McManus et al., 2006; Poulson Brucker et al., 2009; Little et al., 2015; 2016), and forecasts suggest their expansion in a warming world (Stramma et al., 2008; Keeling et al., 2010). To date, only one estimate has been made of the role of upwelling margin sediments in the oceanic mass balance of $\mathrm{Cu}$ (Little et al., 2015), and the isotope composition of the flux of $\mathrm{Cu}$ into margin sediments is unknown. In this study, we present $\mathrm{Cu}$ isotope data for a wide range of reducing environments, including the euxinic Black Sea and Cariaco Basin, and multiple continental margin sites. This dataset provides considerably improved constraints on the reducing sedimentary sink for $\mathrm{Cu}$. 
2.1 The Black Sea

Open ocean euxinia is thought to have been more prevalent at times during Earth's history, particularly along productive margins (Canfield, 1998; Li et al., 2010a; Lyons et al., 2014). Today, however, euxinia is largely restricted to marginal basins, with the Black Sea as the world's largest permanently euxinic basin. The Black Sea is thus frequently cited as an analogue of the Precambrian oceans and for periods of widespread anoxia during the Phanerozoic. Euxinia below $\sim 100 \mathrm{~m}$ water depth in the Black Sea is the result of a positive water balance, moderate primary production, and restricted circulation, with limited inflow and outflow to the Mediterranean Sea via the narrow $(0.76-3.6 \mathrm{~km}$ wide $)$ and shallow ( $<110 \mathrm{~m}$ deep) Bosporus Strait. Total sulphide concentrations increase to $380 \mu \mathrm{M}$ at 2200 $\mathrm{m}$ water depth and are associated with near quantitative removal of $\mathrm{Cu}$ from the dissolved phase (Haraldsson and Westerlund, 1991; Tankéré et al., 2001). The samples analysed in this study have been described previously (Lyons, 1991; Little et al., 2015). Two deep sites underlie the euxinic water column (stations 9 and 14; Fig. 1), while two others are from the shallow shelf and underlie oxic water (stations 16 and 16B; Fig. 1). Station 16B was recovered from a depth close to the modern day chemocline. A broad array of sedimentological observations (Lyons, 1991) and complementary geochemical analyses has been made on these sediments. These include C-S-Fe systematics (Lyons and Berner, 1992; Lyons et al., 1993), S-isotope trends (Lyons, 1997), Fe speciation and isotope patterns (Lyons and Severmann, 2006; Severmann et al., 2008), Mo abundance and isotope compositions (Arnold et al., 2004; Algeo and Lyons, 2006), trace metal concentrations (Little et al., 2015) and $\mathrm{Zn}$ and Ni isotope analyses (Vance et al., 2016a). We present bulk sediment $\mathrm{Cu}$ isotope data for a total of 31 samples from the four locations, all of which are confined to the upper $\sim 25 \mathrm{~cm}$ of the sediment pile at each locality (Fig. 1; see also Little et al., 2015).

\subsection{The Cariaco Basin}

The Cariaco Basin is the world's second largest anoxic basin (Fig. 1, Table 1). It is located on the northern continental shelf off Venezuela and contrasts with the Black Sea in that it has a less restricted hydrographic setting, higher productivity, and higher sedimentation rate. The Cariaco Basin has been euxinic since the last deglaciation (Haug et al., 1998; 
102 Dean et al., 1999; Peterson et al., 2000), but euxinia in the water column is less extreme

103 than that in the Black Sea, with peak total sulphide concentrations of $\sim 65 \mu \mathrm{M}$ (Li et al.,

$1042010 b ; 2011)$. Again, $\mathrm{Cu}$ removal from the water column is observed due to the presence

105 of sulphide (Jacobs et al., 1987). The 22 drill core samples (20 $\mathrm{cm}$ to $8 \mathrm{~m}$ depth) included

106 in this study from ODP Site 1002 span the oxic-euxinic transition at $14.5 \mathrm{ka}$ and the

107 associated redox-related geochemical changes in the core have previously been studied in

108 detail (Lyons et al., 2003; Werne et al., 2003; Lyons and Severmann, 2006; Reinhard et al.,

109 2014; Little et al., 2015).

110

\subsection{Continental Margin sites}

\section{2.3.1 California Borderland basins}

113 The Southern California Bight is a region of elevated primary production, primarily due to

114 coastal upwelling (e.g., Eppley, 1992; Macías et al., 2012). The resultant carbon flux to

115 depth, in combination with related ocean circulation patterns, generates oxygen-deficient

116 waters at depths of $200 \mathrm{~m}$ to $1000 \mathrm{~m}$ along the margin. The Southern California Borderland

117 basins exhibit even lower oxygen contents than equivalent depths along the open margin

118 because the silled topography restricts mixing of basin waters with surrounding seawater

119 (e.g. Emery, 1954; Berelson, 1991). The samples used in this study come from four of the

120 Borderland basins: Santa Barbara, Santa Monica, San Nicolas, and Tanner Basin (Fig. 1).

121 These settings have been characterised geochemically, and samples for this study were

122 taken from expeditions described previously (e.g., McManus et al., 1997; McManus et al.,

123 1998; McManus et al., 2006; Poulson-Brucker et al., 2009; Little et al., 2016).

125 The Santa Barbara and Santa Monica basins are near shore and have sill depths within the

126 region's OMZ. The Santa Barbara basin is the most reducing of the four Borderland basins

127 included for study, though the core studied was sampled just below the sill (sill: $475 \mathrm{~m}$,

128 core site: 493 m; Poulson-Brucker et al., 2009). Dissolved sulphide is present to varying

129 degrees within the shallow sediment package and has been observed at low $(<15 \mathrm{nM})$

130 levels in the water column (e.g., Kuwabara et al., 1999; Zheng et al., 2000). These

131 observations, coupled with the fact that the shallow pore fluids (upper 3-8 cm, with

132 sulphide appearing below) are ferruginous (e.g., Kuwabara et al., 1999; Zheng et al.,

133 2000), imply that iron reduction and sulphate reduction are dominant electron transfer

134 pathways within the shallow sediment package. The mass accumulation rate in Santa 
135 Barbara is the highest of all the sites studied (Table 1), which is largely the result of high

136 fluxes of lithogenic material (Thunell et al., 1995).

138 The Santa Monica sill is at $740 \mathrm{~m}$, the basin floor is at $910 \mathrm{~m}$, and the sediment core was

139 collected at $905 \mathrm{~m}$. Bottom-water oxygen concentrations vary within the basin but are

140 generally 2 - $10 \mu \mathrm{M}$ (Berelson, 1991; Stott et al., 2000; Berelson et al., 2005; McManus et

141 al., 2006). Like Santa Barbara basin, shallow pore fluids in Santa Monica are ferruginous

142 (e.g., Shaw et al., 1990; McManus et al., 1997; 1998). Although Shaw et al. (1990) report a

143 thin $(\sim 1 \mathrm{~cm})$ layer of extractable $\mathrm{Fe}$ at the sediment-water boundary, transfer of dissolved

144 Fe occurs across this boundary (McManus et al., 1997; Elrod et al., 1991; Severmann et al.,

145 2010). To our knowledge there are no reports of shallow sediment-column or bottom-water

146 accumulation of dissolved sulphide; net sulphate reduction is nevertheless an important

147 pathway for electron transport, as manifest in iron sulphide minerals that form within the

148 sediments (Berelson et al., 1996).

150 The offshore basins, San Nicolas and Tanner, have sill depths at $1100 \mathrm{~m}$ and $1160 \mathrm{~m}$, 151 respectively, below the depth of the most intense oxygen deficiency. Tanner Basin is 152 further offshore than San Nicolas (Emery, 1960). Maximum water depths in the San 153 Nicolas basin are $1832 \mathrm{~m}$ (core collected at $1750 \mathrm{~m}$ ), with bottom-water oxygen contents 154 of $\sim 30 \mu \mathrm{M}$ (Shaw et al., 1990). Pore fluids from the upper $10 \mathrm{~cm}$ are rich in dissolved $\mathrm{Mn}$, 155 with strong increases in Mn appearing just below the sediment-water interface (Shaw et al., 156 1990). Dissolved Fe concentrations increase below $\sim 2 \mathrm{~cm}$, with much lower Fe

157 concentrations in the upper sediment package compared to those in the basins nearer to 158 shore (Shaw et al., 1990). The Tanner Basin reaches a maximum depth of $1550 \mathrm{~m}$, and the 159 core was collected at $1514 \mathrm{~m}$. Bottom water oxygen contents are $\sim 30 \mu \mathrm{M}$. Sediments in 160 this basin also exhibit pore fluid Fe and Mn enrichments, but the concentrations of both are 161 lower than those in San Nicolas Basin sediments (c.f., Shaw et al., 1990; McManus et al., 1621997 ; 1998). Despite differences in dissolved metal concentrations, these two basins are 163 quite similar diagenetically, with Tanner having an estimated sediment depth of oxygen 164 penetration that is slightly shallower than in San Nicolas (e.g., 0.4 vs. $0.5 \mathrm{~cm}$, Berelson et 165 al., 1996) and slightly higher total organic carbon contents ( $\sim 6 \mathrm{wt} \%$ vs. $\sim 4.5 \mathrm{wt} \%$; Little et 166 al., 2016). 
170 Oxygen deficiency is more pronounced along the Mexican margin compared to the

171 California margin, with oxygen concentrations of $<1 \mu \mathrm{M}$ at our study sites (Chong et al., 2012). This OMZ extends more than $1500 \mathrm{~km}$ off the coast of Mexico (Sansone et al., 2004), and anaerobic diagenetic processes dominate in sediments where the OMZ intercepts the seafloor (Berelson et al., 2005). Of the three sites included in this study, two are from the open ocean margin off Baja California (Magdalena and the Soledad Basin), and the other is from the Pescadero Slope, which is at the eastern edge of the mouth of the Gulf of California (Chong et al., 2012) (Fig. 1).

The Magdalena site is situated on the western margin of Baja California at $692 \mathrm{~m}$ water depth. The upper $1-2 \mathrm{~cm}$ of the sediment core is bioturbated, and organic carbon contents are particularly high $(\sim 11 \%)$. Dissolved sulphide appears in pore waters at $3 \mathrm{~cm}$ depth (2 $\mu \mathrm{M})$ and increases rapidly at depths greater than $20 \mathrm{~cm}$ (Chong et al., 2012). The Soledad Basin is also on the western side of Baja California and has an effective sill depth of $\sim 250$ m (Silverberg et al., 2004). The core studied here was collected at $544 \mathrm{~m}$ water depth, close to the deepest point of the basin $(545 \mathrm{~m})$. Sediments at this site are laminated (including extensive traceable coccolith laminae; van Geen et al., 2003), with sulphide $(\sim 10 \mu \mathrm{M})$ in pore waters close to the sediment-water interface and increasing below $8 \mathrm{~cm}$ (to $>40 \mu \mathrm{M}$ ) (Chong et al., 2012). Because of the high sulphide concentrations, dissolved iron is titrated from the pore fluids at relatively shallow depths (Chong et al., 2012). Clastic input on the open ocean side of Baja California is low, but sediment accumulation rates are high, particularly in the Soledad Basin, due to elevated productivity (Sansone et al., 2004; Table 1). Clastic input is high along the Pescadero slope, due to the location of this coring site on the eastern edge of the mouth of the Gulf of California, where it receives continental drainage from the Sierra Madre Occidental Mountains (e.g., Berelson et al., 2005; Chong et al., 2012). The laminated sediment core discussed in this study was taken at $616 \mathrm{~m}$, close to the centre of the OMZ (at $\sim 600 \mathrm{~m}$ ). High concentrations of dissolved Fe have been reported from the pore waters of this site, rising from near zero to $260 \mu \mathrm{M}$ within the first 2 $\mathrm{cm}$ (Chong et al., 2012), compared to peaks of $\sim 10 \mu \mathrm{M}$ at $3 \mathrm{~cm}$ for the Magdalena site and $\mathrm{a} \sim 65 \mu \mathrm{M}$ peak in the upper $1 \mathrm{~cm}$ of the Soledad sediment core. Chong et al. (2012) classified the Pescadero site as Fe-rich, Magdalena as Fe-rich/sulphidic, and Soledad Basin as sulphidic. 
204 The Peru margin is an open ocean margin setting with high upwelling-driven productivity

205 and an associated intense OMZ at depths of $\sim 100$ to $700 \mathrm{~m}$ (Emeis et al., 1991; Lückge and

206 Reinhardt. 2000). The core used in our study (Fig. 1, see also McManus et al., 2006; Little

207 et al., 2015; 2016) was collected at $264 \mathrm{~m}$, with bottom-water oxygen concentrations of

$208<10 \mu \mathrm{M}$. Bulk sediments contain $\sim 15 \%$ organic carbon and $>1 \%$ total sulphur (McManus

209 et al., 2006; Little et al., 2016). This combination of high organic carbon and low oxygen

210 results in intense anerobic diagenesis, with prior work demonstrating the potential for

211 reduced iron fluxes across the sediment water interface (Noffke et al., 2012; Scholz et al.,

212 2014). Episodic efflux of sulphide has also been reported further south along the Peruvian

213 margin (Schunck et al., 2013).

215 Figure 1. Locations of sites included for study. The Peru margin site (site MC82; Table 1;

216 McManus et al., 2006) is from the core of the Peruvian OMZ. The California Borderland

217 Basins (N Pacific Margin Sites inset) comprise: Barb - Santa Barbara Basin, Mon - Santa

218 Monica Basin, Nic - San Nicolas Basin and Tan - Tanner Basin. The Mexican margin

219 sites (N Pacific Margin Sites inset) comprise: Sol - Soledad Basin, Mag - Magdalena

220 margin and Pesc - Pescadero Slope. The Cariaco Basin samples are from spliced cores A

221 and B at Site 1002 of Leg 165 of the Ocean Drilling Program (see inset). Samples from

222 four Black Sea stations were analysed: two underly the deep euxinic water column

223 (Stations 9 and 14) and two are from the shallow oxic shelf region (Stations 16 and 16B).

224 Maps were made using Ocean Data View software (odv.awi.de; Schlitzer, 2015).

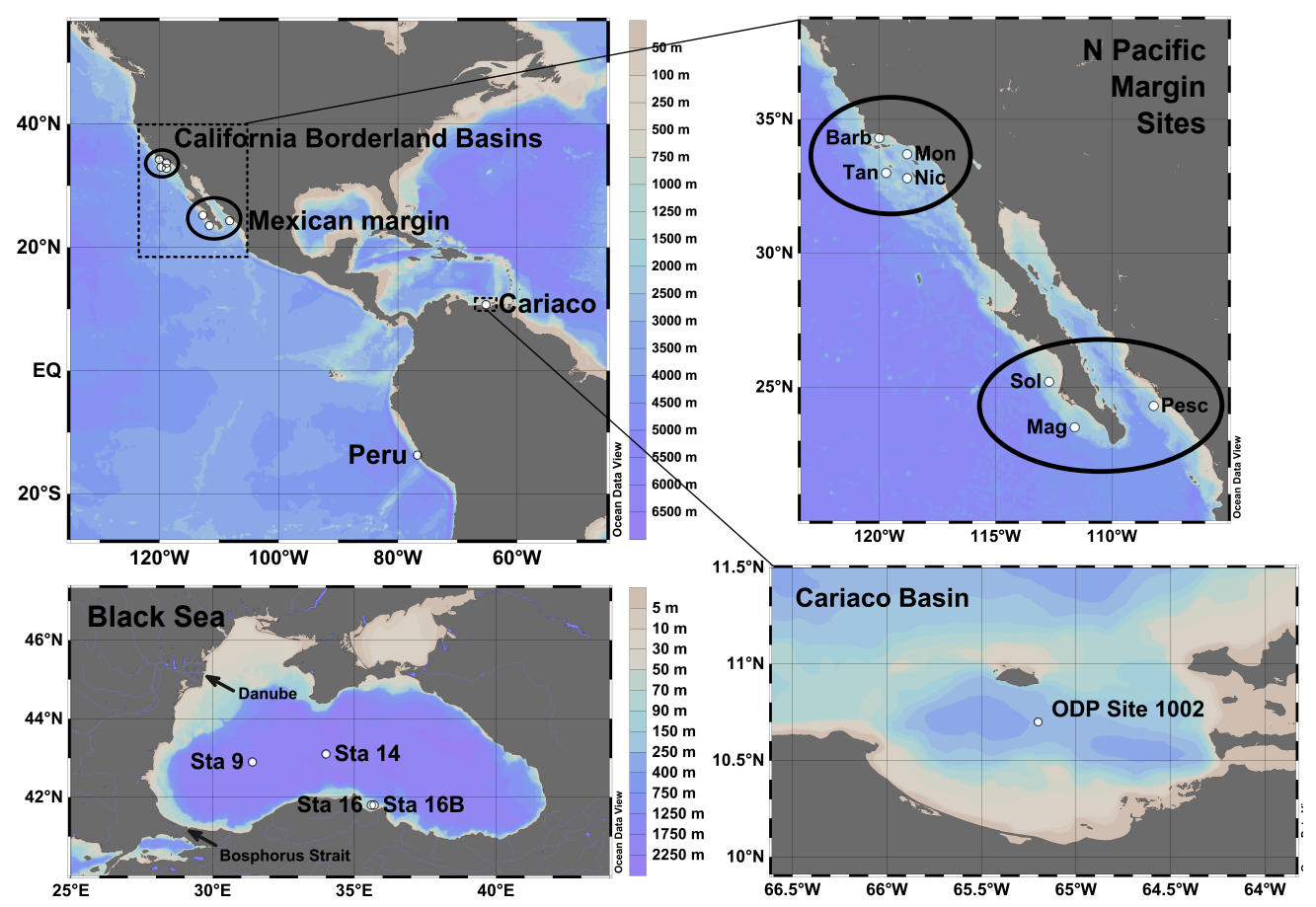




\section{Methods}

229

\subsection{Elemental concentrations and $\mathrm{Cu}$ isotope data}

231 All work was carried out under trace metal clean conditions, with MilliQ water (18.2 $\Omega)$

232 and Savillex PFA labware. Acids and reagents used were either ultrapure $\left(\mathrm{HF}, \mathrm{H}_{2} \mathrm{O}_{2}\right)$ or

233 double distilled $\left(\mathrm{HNO}_{3}, \mathrm{HCl}\right)$. Sample digestion and analytical methods have been

234 described previously (Little et al., 2014a; 2015). In brief, dilute nitric acid was added

235 dropwise to 50-500 $\mathrm{mg}$ of powdered sediment until effervescence ceased (signalling

236 complete dissolution of carbonate). The sediment was then digested in a 3:1 mix of

237 concentrated $\mathrm{HF}$ and concentrated $\mathrm{HNO}_{3}$ for 48 hours. Digestion was followed by triple

238 treatment with concentrated $\mathrm{HNO}_{3}$ to remove fluoride salts before dissolution in $7 \mathrm{M} \mathrm{HCl}$.

239 An aliquot of these solutions was analysed for multi-element concentrations on a

240 ThermoFinnigan Element 2 at the University of Bristol or a ThermoFinnigan Element XR

241 at ETH Zürich.

243 After elemental analysis, an aliquot of the total digest solution was taken for $\mathrm{Cu}$ isotope

244 purification using a two-stage anion exchange procedure (Bio-Rad AG MP-1M resin)

245 modified from Maréchal et al. (1999) and detailed previously (Archer and Vance, 2004;

246 Vance et al., 2008; Little et al., 2014a). Final $\mathrm{Cu}$ concentrations for analysis were $\sim 100$

$247 \mathrm{ppb}$, dissolved in $\sim 1 \mathrm{ml} 2 \% \mathrm{HNO}_{3}$. Isotopic analyses were carried out on a

248 ThermoFinnigan Neptune MC-ICP-MS at the University of Bristol or a Neptune Plus at

249 ETH Zürich, in low-resolution mode with introduction via a CPI PFA nebuliser (50

$250 \mu \mathrm{l} / \mathrm{min})$ or a Savillex C-Flow PFA nebuliser $(50 \mu \mathrm{l} / \mathrm{min})$ attached to a glass spray chamber.

251 Copper isotope ratios for samples were calculated using a standard bracketing approach by

252 comparison to pure untreated NIST SRM 976 and are reported relative to this standard in

253 delta-notation:

254

$\delta^{65} \mathrm{Cu}=1000\left[\frac{\left({ }^{65} \mathrm{Cu} /{ }^{63} \mathrm{Cu}\right)_{\text {sample }}}{\left({ }^{65} \mathrm{Cu} /{ }^{63} \mathrm{Cu}\right)_{\text {SRM976 }}}-1\right]$

256 The long-term reproducibility of a secondary pure $\mathrm{Cu}$ standard was $\delta^{65} \mathrm{Cu}=+0.11 \pm$ $2570.11 \%$ o $(\mathrm{n}=102)$ and $+0.11 \pm 0.06 \%$ o $(\mathrm{n}=112)$ at Bristol and ETH Zürich respectively, 258 compared to $+0.10 \pm 0.06 \%$ measured at the Hebrew University (Asael et al., 2007). The 
USGS reference materials BHVO-2, BIR-1A, BCR-2, and Nod P1 were analysed to assess accuracy. All uncertainties are given as $2 \mathrm{SD}$, unless stated otherwise.

\section{Results}

Accuracy and reproducibility of measured $\mathrm{Cu}$ and $\mathrm{Al}$ concentrations for two secondary standards - the commercially available SLRS-5 river standard from the National Research Council Canada and USGS Green River Shale SGR-1 - are reported in Table 2. Note that all $\mathrm{Cu} / \mathrm{Al}$ ratios are given by mass, in $\mathrm{ppm} \mathrm{Cu} / \mathrm{wt} \% \mathrm{Al}$ (i.e., $\times 10^{-4}$ ). Copper isotope data for USGS reference materials are reported in Table 3. Values for BHVO-2, BIR-1A and BCR2 fall within the ranges recommended in Moynier et al. (2017). Values obtained for NodP1 are consistent with that reported by Bigalke et al. (2010), and with the published mean for global Fe-Mn crusts and nodules $+0.31 \pm 0.12 \%$ ( $1 \mathrm{SD}, \mathrm{n}=31$; Data sources: Albarède, 2004; Little et al., 2014a).

\subsection{Cu/Al ratios and $\mathrm{Cu}$ isotope data}

Down-core $\mathrm{Cu} / \mathrm{Al}$ and $\delta^{65} \mathrm{Cu}_{\text {bulk }}$ data are presented graphically in Figures $2-5$ and tabulated in full in the electronic supplementary material (ESM Table 1) and summarised in Table 4 (site-by-site averages). Where available, plotted isotope data are compared to mean values for proximal oxic sediments (Black Sea: oxic Station 16, Cariaco Basin: oxic section of core). In other locations, comparisons are made to the published average lithogenic $\mathrm{Cu}$ isotope composition $\left(\delta^{65} \mathrm{Cu}_{\text {lith }}=+0.08 \pm 0.17 \%\right.$, $1 \mathrm{SD}, \mathrm{n}=334$; Moynier et al., 2017).

Aluminium is assumed to be immobile during diagenesis and is used as a tracer of the lithogenic component of the sediment. To accurately define the non-lithogenic sedimentary $\mathrm{Cu}$ component, measured $\mathrm{Cu} / \mathrm{Al}$ ratios should ideally be compared to the $\mathrm{Cu} / \mathrm{Al}$ ratio of local lithogenic background material (e.g., Böning et al., 2012; Little et al., 2015). In this study, the local background is taken as the minimum measured $\mathrm{Cu} / \mathrm{Al}$ ratio from proximal oxic sediments where available (Black Sea, Cariaco Basin), following Böning et al. (2012). In the absence of an estimate for the local lithogenic background sedimentation in the

290 California Borderland Basins, we compare $\mathrm{Cu} / \mathrm{Al}$ ratios in Figure 4 with the most recent 291 upper continental crust (UCC) estimate of $3.5 \times 10^{-4}$ (Rudnick and Gao, 2003). The

292 lithogenic background for sediments deposited close to Peru has previously been 
approximated to that of a Peruvian andesite (Böning et al., 2004; Scholz et al., 2011; Little et al., 2015). A Cu/Al ratio of $4.5 \times 10^{-4}$ can be calculated for average andesite from the

295 Central Volcanic Zone of Peru (values derived from the GEOROC database of the Max-

296 Planck Institute for Chemistry, Mainz, Germany; Sarbas and Nohl, 2009). A similar value

297 of $4.0 \times 10^{-4}$ can be calculated for a compilation of Trans Mexican Volcanic Belt samples

298 (also derived from the GEOROC database). It is to this range of values $\left(4.0-4.5 \times 10^{-4}\right)$

299 that samples from the Mexican and Peru margins are compared in Figure 5.

301 Elevated $\mathrm{Cu} / \mathrm{Al}$ ratios compared to the (local) lithogenic background (Figures 2 - 5) are

302 indicative of the presence of authigenic (chemically precipitated or scavenged) and/or

303 biogenic (cellular and/or skeletal) $\mathrm{Cu}$, which together are termed the 'bioauthigenic'

304 fraction (after Little et al., 2016). Note that the biogenic (or uptake-derived) component of

$305 \mathrm{Cu}$ in the sediment is predicted to be small $(<20 \%$; Little et al., 2015), but that scavenging

306 of $\mathrm{Cu}$ by particulate organic carbon is likely an important route by which $\mathrm{Cu}$ is delivered to 307 the sediment.

\subsubsection{Black Sea}

$310 \mathrm{Cu} / \mathrm{Al}$ and $\delta^{65} \mathrm{Cu}$ data for the four Black Sea sites are presented in Figure 2. Sediments

311 from oxic Station 16 are assumed to represent the local lithogenic background

312 sedimentation (mean $\mathrm{Cu} / \mathrm{Al}=5.3 \pm 0.5 \times 10^{-4}$, minimum $\mathrm{Cu} / \mathrm{Al}=4.8 \times 10^{-4}$ ). In support of

313 this assumption, these sediments have a lithogenic $\mathrm{Cu}$ isotope composition with an average

$314 \delta^{65} \mathrm{Cu}$ of $+0.04 \pm 0.07 \%$. Chemocline Station $16 \mathrm{~B}$ shows $\mathrm{Cu} / \mathrm{Al}$ ratios (mean $\mathrm{Cu} / \mathrm{Al}=5.7 \pm$

$3150.9 \times 10^{-4}$ ) very close to those of oxic Station 16, suggesting no significant bioauthigenic

316 enrichment, except for the two surface-most samples $\left(\mathrm{Cu} / \mathrm{Al}=6.5\right.$ and $6.1 \times 10^{-4}$ at $0-2$

$317 \mathrm{~cm}$ and $2-4 \mathrm{~cm}$ respectively). However, despite dominantly lithogenic $\mathrm{Cu} / \mathrm{Al}$ ratios,

318 samples from Station $16 \mathrm{~B}$ exhibit heavier and more variable $\delta^{65} \mathrm{Cu}$, with an average of

$319+0.14 \pm 0.15 \%$. The two upper-most samples (both at $+0.25 \%$ ) again exhibit the greatest

320 deviation from lithogenic values. The two euxinic stations 9 and 14 are indistinguishable

321 and isotopically heavy compared to lithogenic $\mathrm{Cu}$ (Station 9: $+0.30 \pm 0.12 \%$, Station 14:

$322+0.32 \pm 0.05 \%$ ), despite slightly more elevated $\mathrm{Cu} / \mathrm{Al}$ ratios at Station 9 compared to

323 Station 14 (mean Cu/Al at Station $9=26.9 \pm 9.2 \times 10^{-4}$ compared to $17.6 \pm 5.5 \times 10^{-4}$ for

324 Station 14). The mean $\delta^{65} \mathrm{Cu}$ for all Black Sea euxinic samples is $+0.31 \pm 0.10 \%$. 
326 Figure 2. Down-core $\mathrm{Cu} / \mathrm{Al}$ and bulk $\delta^{65} \mathrm{Cu}$ data for the four Black Sea sites. Ox - Station 327 16, Chem - Station 16B, Eux-9 - Station 9, Eux-14 - Station 14. The local lithogenic

328 background, which is taken as the minimum $\mathrm{Cu} / \mathrm{Al}$ and mean $\delta^{65} \mathrm{Cu}$ at oxic Station 16 , is 329 given as a dashed black line. The error bar represents 2 SD external reproducibility on $\mathrm{Cu}$ 330 isotope measurements from Bristol MC-ICP-MS (0.11\%).
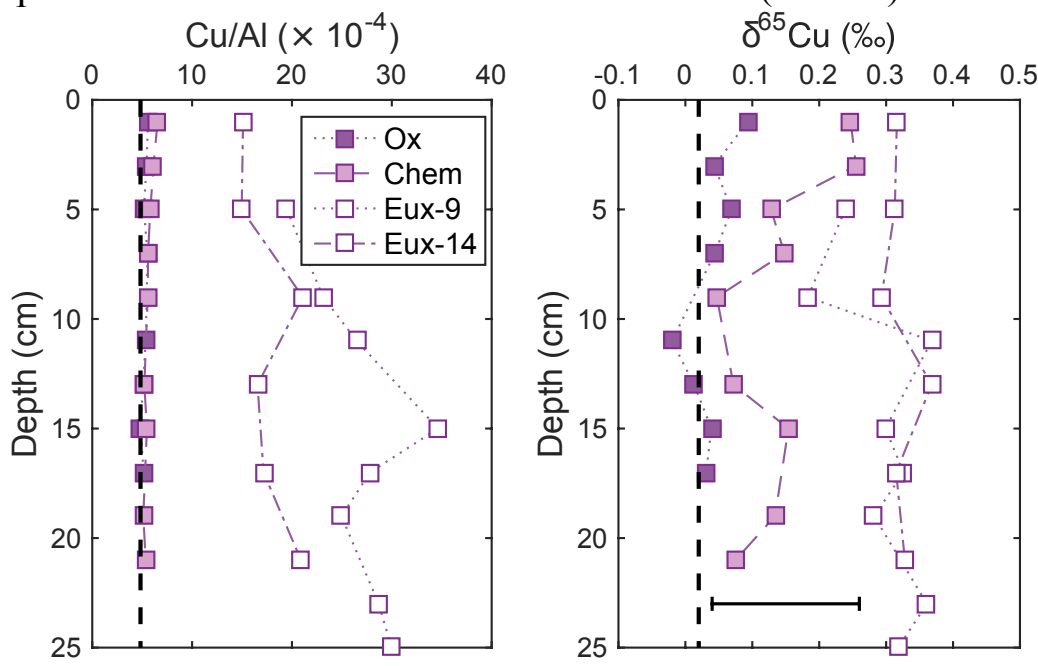

\subsubsection{Cariaco Basin}

$334 \mathrm{Cu} / \mathrm{Al}$ and $\delta^{65} \mathrm{Cu}$ data for the Cariaco Basin drill-core samples are presented in Figure 3.

335 The lowermost four samples represent deposition under oxic conditions linked to the sea-

336 level low stand of the last glacial period (Lyons et al., 2003). These four oxic samples have

337 a lithogenic $\delta^{65} \mathrm{Cu}$ of $+0.08 \pm 0.06 \%$ and an average $\mathrm{Cu} / \mathrm{Al}$ ratio of $5.2 \pm 1.0 \times 10^{-4}$, which

338 is elevated compared to average UCC (at $3.1-3.5 \times 10^{-4}$ ). The euxinic (interglacial)

339 sediments have a lower average $\mathrm{Cu} / \mathrm{Al}$ ratio $\left(4.5 \pm 0.8 \times 10^{-4}\right)$ and significantly heavier $\mathrm{Cu}$

340 isotope values compared to those deposited under oxic conditions, with a mean $\delta^{65} \mathrm{Cu}=$

$341+0.20 \pm 0.06 \%$. If the four oxic samples are assumed to represent the local lithogenic

342 input, euxinic sediments in the Cariaco Basin show no bioauthigenic enrichment in $\mathrm{Cu}$

343 over the lithogenic background value (Fig. 3). 
346 Figure 3. Down-core $\mathrm{Cu} / \mathrm{Al}$ and bulk $\delta^{65} \mathrm{Cu}$ data for the Cariaco Basin core. Lowermost

347 four samples (filled stars, 'Ox') were deposited during the last glacial period, under oxic conditions. The remainder of the sediment core was deposited during the present interglacial, when the water column was euxinic (crosses, 'Eux'). The grey bar represents a range of possible lithogenic $\mathrm{Cu} / \mathrm{Al}$ ratios (including $\mathrm{UCC}$ and the local oxic minimum from the glacial period samples). The dashed line represents global mean lithogenic $\delta^{65} \mathrm{Cu}$ (Moynier et al., 2017). The error bar represents 2 SD external reproducibility on $\mathrm{Cu}$ isotope measurements from ETH MC-ICP-MS (0.06\%).
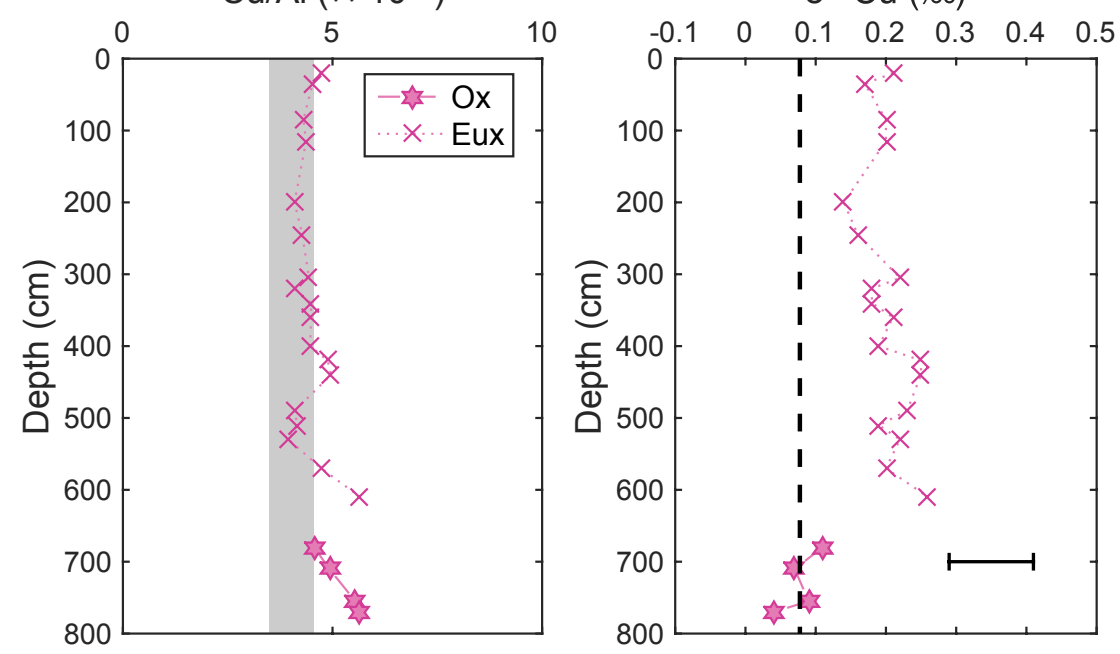

\subsubsection{California Borderland Basins}

357 The most reducing of the four California Borderland sites, Santa Barbara, exhibits little or no bioauthigenic enrichment of $\mathrm{Cu}\left(\right.$ mean $\left.\mathrm{Cu} / \mathrm{Al}=4.5 \pm 0.8 \times 10^{-4}\right)$ with $\delta^{65} \mathrm{Cu}$ values $\left(\delta^{65} \mathrm{Cu}=+0.04 \pm 0.09 \%\right.$ o $)$ that are unfractionated from lithogenic values. Santa Monica Basin, which has ferruginous porewaters, exhibits higher $\mathrm{Cu} / \mathrm{Al}$ ratios and slightly isotopically heavy $\mathrm{Cu}$, particularly the surface-most sample $\left(\mathrm{Cu} / \mathrm{Al}\right.$ at $1.5 \mathrm{~cm}=11.4 \times 10^{-4}$ cf. mean $\mathrm{Cu} / \mathrm{Al}$ at depths $>1.5 \mathrm{~cm}=6.5 \pm 0.3 \times 10^{-4} ; \delta^{65} \mathrm{Cu}$ at $1.5 \mathrm{~cm}=+0.18 \%$ off. mean $\delta^{65} \mathrm{Cu}>1.5 \mathrm{~cm}=+0.11 \pm 0.05 \%$; Fig. 4). Note that an anthropogenic source of metals has been identified at this site, and this may contribute to the enrichment observed in the surface $1-2 \mathrm{~cm}$ (Finney and Huh, 1989; Bruland et al., 1994). San Nicolas, where porewaters can be defined as manganous, also has a surface-most sample that is isotopically heavier than the remainder of the sediment core (at $+0.31 \%$ versus $+0.12 \pm$ 0.04\%; Fig. 4). Copper throughout this core is significantly enriched (mean $\mathrm{Cu} / \mathrm{Al}=10.9 \pm$ $4.8 \times 10^{-4}$ ) relative to UCC. The most $\mathrm{Cu}$ enriched of the California Borderland Basin sites is Tanner Basin. Mean $\mathrm{Cu} / \mathrm{Al}$ ratios at this site are $18.1 \pm 6.5 \times 10^{-4}$ and $\mathrm{Cu}$ is isotopically heavy compared to lithogenic $\mathrm{Cu}$ at $+0.24 \pm 0.06 \%$. 
373 Figure 4. Down-core $\mathrm{Cu} / \mathrm{Al}$ and bulk $\delta^{65} \mathrm{Cu}$ data for the California Borderland basins. Barb 374 - Santa Barbara basin, Mon - Santa Monica basin, Nic - San Nicolas basin, Tan - Tanner 375 basin. Estimates of the lithogenic background (UCC Cu/Al: Rudnick and Gao, 2003;

376 global mean lithogenic $\delta^{65} \mathrm{Cu}$; Moynier et al., 2017) are given as a dashed black line. Error 377 bar represents 2 SD external reproducibility on $\mathrm{Cu}$ isotope measurements from ETH MC378 ICP-MS (0.06\%).
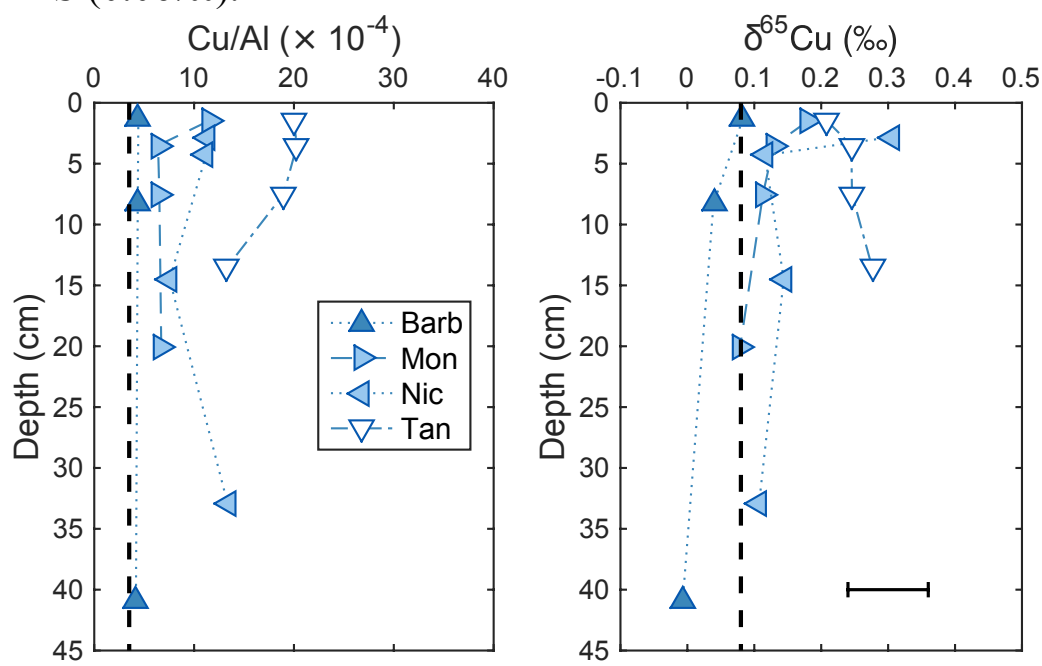

379

380

381

\subsubsection{Mexican and Peru Margins}

382

The Peru margin exhibits the highest absolute $\mathrm{Cu}$ concentrations of any of the sites analysed here (up to $75 \mathrm{ppm}$ ). Enrichment is greatest close to the sediment surface and declines with depth (Fig. 5; mean $\mathrm{Cu} / \mathrm{Al}=22.6 \pm 4.2 \times 10^{-4}$ ). Copper isotope values at this site are homogeneous with depth and isotopically heavy compared to the lithogenic baseline $\left(\delta^{65} \mathrm{Cu}=+0.32 \pm 0.07 \%\right.$; Fig. 5).

The Magdalena and Peru margin sites are similar in their $\mathrm{Cu}$ geochemistry. The Magdalena margin also exhibits high $\mathrm{Cu} / \mathrm{Al}$ ratios $\left(22.1 \pm 4.4 \times 10^{-4}\right)$ and isotopically heavy $\delta^{65} \mathrm{Cu}$ $(+0.20 \pm 0.12 \%)$. By contrast, the sites of Soledad Basin $\left(\mathrm{Cu} / \mathrm{Al}=7.3 \pm 0.6 \times 10^{-4}\right)$ and

391 Pescadero Slope $\left(\mathrm{Cu} / \mathrm{Al}=3.0 \pm 0.2 \times 10^{-4}\right)$ are only moderately elevated or not enriched (or even slightly depleted), respectively. These two sites are isotopically indistinguishable and exhibit slightly heavier $\mathrm{Cu}$ isotope values compared to typical lithogenic signatures (Soledad: $+0.15 \pm 0.06 \%$; Pescadero: $+0.14 \pm 0.10 \%$ ). 
397 Figure 5. Down-core $\mathrm{Cu} / \mathrm{Al}$ and bulk $\delta^{65} \mathrm{Cu}$ data for the Mexican and Peru margin sites.

398 Pesc - Pescadero slope, Sol - Soledad basin, Mag - Magdalena margin, Peru - Peru

399 margin. Grey bar gives range of Peruvian andesite-Mexican volcanic zone $\mathrm{Cu} / \mathrm{Al}$ ratios, 400 see text in section 4.1 for details. Dashed black line represents global mean lithogenic $401 \delta^{65} \mathrm{Cu}$ (Moynier et al., 2017). Error bar represents $2 \mathrm{SD}$ external reproducibility on $\mathrm{Cu}$ 402 isotope measurements from ETH MC-ICP-MS (0.06\%).
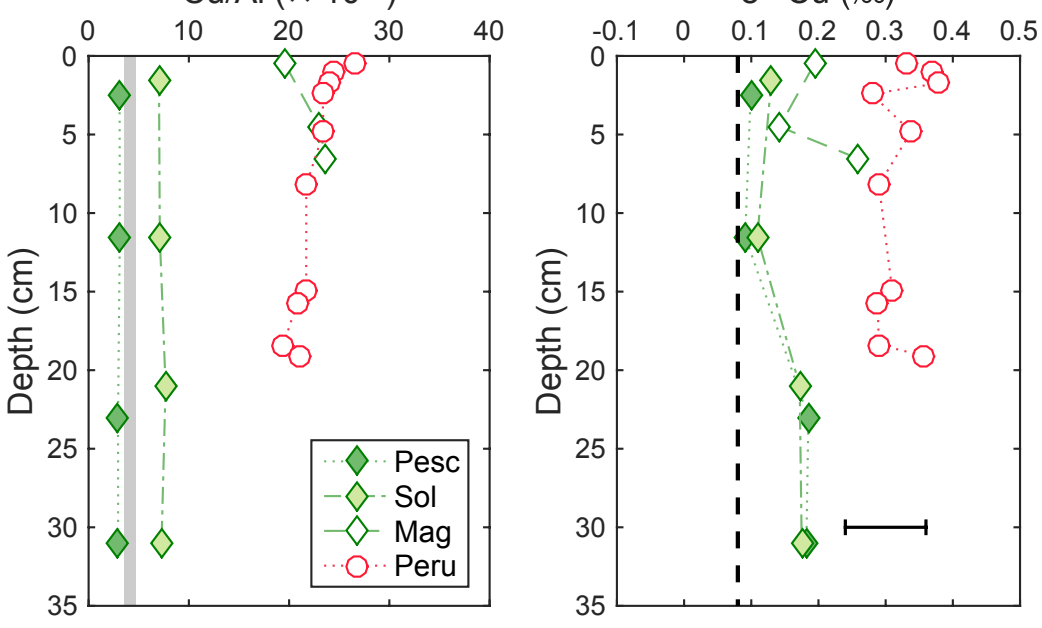

\section{Discussion}

406

\subsection{Covariation of $\delta^{65} \mathrm{Cu}$ and $\mathrm{Al} / \mathrm{Cu}$ in marine sediments}

408

As a whole, the dataset presented here shows limited variability in $\delta^{65} \mathrm{Cu}$ values, from $0.02 \%$ to $+0.37 \%$. For comparison, the measured range in $\delta^{65} \mathrm{Cu}$ found for typical Earth surface materials spans approximately $-1.5 \%$ to $+2 \%$ (e.g., Moynier et al., 2017), though this range is extended considerably with the inclusion of $\mathrm{Cu}$-bearing ore minerals $(-16.5 \%$ to $+10.0 \%$; Mathur et al., 2009).

415 All samples from this study are isotopically lighter than data for the dissolved phase in 416 seawater (at +0.6 to $+0.9 \%$, Fig. 6; Vance et al., 2008; Thompson et al., 2014; Takano et 417 al., 2014). A negative correlation (Fig. 6; $\mathrm{R}_{\text {all data }}^{2}=0.40, \mathrm{p}<0.001$ ) is observed between $418 \delta^{65} \mathrm{Cu}$ values and $\mathrm{Al} / \mathrm{Cu}$ ratios. This relationship can be explained, to a first order, by 419 mixing of two distinct end-member sources of $\mathrm{Cu}$. The first is a lithogenic source, with a 420 high $\mathrm{Al} / \mathrm{Cu}$ ratio and a lithogenic $\mathrm{Cu}$ isotope composition of $\sim 0$ to $+0.1 \%$ (grey box, Fig.

421 6). The second mixing component can be termed the bioauthigenic $\mathrm{Cu}$ end member. It has 422 a low $\mathrm{Al} / \mathrm{Cu}$ ratio and an isotope composition of about $+0.3 \%$. While the presence of a 423 lithogenic end member is intuitive, the fact that just one other component can explain a 
significant fraction of the variability in the remainder of the dataset is unexpected and

425 merits further discussion.

427 Figure 6. Covariation of $\delta^{65} \mathrm{Cu}$ with $\mathrm{Al} / \mathrm{Cu}$ in marine sediments. Each site is represented 428 by its mean $\delta^{65} \mathrm{Cu}$ and $\mathrm{Al} / \mathrm{Cu}$ values $\pm 2 \mathrm{SD}$ error bars. Symbols for each site are the same 429 as in Figures $2-5$. The range of estimated bulk seawater isotopic compositions ( +0.6 to $430+0.9 \%$ ) is shown as a shaded blue bar. The range and mean of lithogenic $\mathrm{Al} / \mathrm{Cu}$ values and $431 \delta^{65} \mathrm{Cu}$ ratios are shown as a grey box. For comparison, the mean and $1 \mathrm{SD}$ of the surface 432 layers of global Fe-Mn oxide sediments is shown as an orange star.

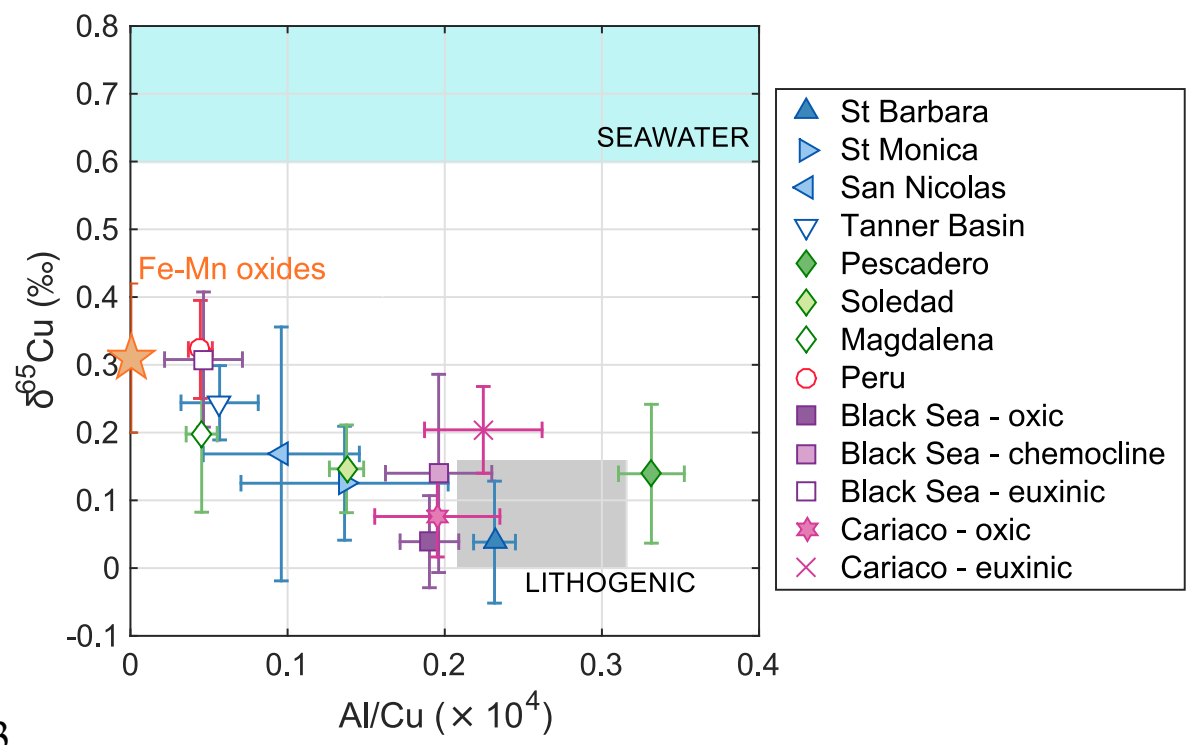

434 The isotope composition of the bioauthigenic $\mathrm{Cu}$ component of the sediment can be 435 calculated for individual samples by mass balance, assuming a $\mathrm{Cu} / \mathrm{Al}$ ratio and $\delta^{65} \mathrm{Cu}$ value 436 of the lithogenic background material $\left(\mathrm{Cu} / \mathrm{Al}_{\text {lith }}\right.$ and $\left.\delta^{65} \mathrm{Cu}_{\text {lith }}\right)$. First, the lithogenic fraction $437\left(\mathrm{X}_{\text {lith }}\right)$ of the total $\mathrm{Cu}$ is calculated:

$$
\mathrm{X}_{\text {lith }}=\frac{\frac{\mathrm{Cu}}{\mathrm{Al}} \times \mathrm{Alth}_{\text {ith }} \times \mathrm{Al}_{\text {sample }}}{\mathrm{Cu}_{\text {sample }}},
$$

where $\mathrm{Al}_{\text {sample }}$ and $\mathrm{Cu}_{\text {sample }}$ are the measured bulk $\mathrm{Al}$ and $\mathrm{Cu}$ concentrations of the sample.

The bioauthigenic $\delta^{65} \mathrm{Cu}_{\text {auth }}$ value can then be calculated:

$$
\delta^{65} \mathrm{Cu}_{\text {auth }}=\frac{\left(\delta^{65} \mathrm{Cu}_{\text {bulk }}-\delta^{65} \mathrm{Cu}_{\mathrm{lith}} \cdot \mathrm{X}_{\mathrm{lith}}\right)}{\mathrm{X}_{\text {auth }}},
$$

where $\delta^{65} \mathrm{Cu}_{\text {bulk }}$ is the measured $\delta^{65} \mathrm{Cu}$ ratio of the sample, and $\mathrm{X}_{\text {auth }}$ is the fraction of bioauthigenic $\mathrm{Cu}$ (i.e., $\mathrm{X}_{\text {auth }}=1-\mathrm{X}_{\text {lith }}$ ). This calculation is straightforward but gives unreasonable values when the lithogenic fraction is very large $(>90 \%)$. This situation 
applies to the Cariaco Basin, the Santa Barbara Basin, and the Pescadero Slope sites, which all show little or no bioauthigenic enrichment. Excluding these three sites, and assuming lithogenic $\mathrm{Cu} / \mathrm{Al}_{\text {lith }}$ and $\delta^{65} \mathrm{Cu}_{\text {lith }}$ values for the remaining sites as detailed in section 4.1 , the calculated bioauthigenic end member has a $\mathrm{Cu}$ isotope composition of $+0.31 \pm 0.11 \%$ o ( $\mathrm{SD}, \mathrm{n}=43$; see ESM Table 1 for sample-by-sample calculated $\delta^{65} \mathrm{Cu}_{\text {auth }}$ values). Exclusion of the Black Sea data yields a margin-only $\delta^{65} \mathrm{Cu}_{\text {auth }}$ of $+0.28 \pm 0.11 \%$ ( $(1 \mathrm{SD}, \mathrm{n}=29)$. Note that using a single $\mathrm{Cu} / \mathrm{Al}_{\text {lith }}$ value for all sites and varying this ratio between 3.0 and $4.5 \times 10^{-4}$ alters the calculated $\delta^{65} \mathrm{Cu}_{\text {auth }}$ by less than $\pm 0.02 \%$. The calculation is somewhat more sensitive to the assumed $\delta^{65} \mathrm{Cu}_{\text {lith }}$ value. Taking the published mean $\delta^{65} \mathrm{Cu}_{\text {lith }} \pm 1 \mathrm{SD}$ (where $\delta^{65} \mathrm{Cu}_{\text {lith }}=0.08 \pm 0.17 \%$; Moynier et al., 2017) - i.e. using a range for $\delta^{65} \mathrm{Cu}_{\text {lith }}$ of 0.09 to $+0.25 \%$ - gives a range in the calculated mean $\delta^{65} \mathrm{Cu}_{\text {auth }}$ of +0.39 to $+0.23 \%$.

460

The calculated bioauthigenic end member isotope composition of about $+0.3 \%$ closely corresponds to observed values for the surface layers of Fe-Mn crusts and nodules (orange star in Fig. 6; mean $\delta^{65} \mathrm{Cu}_{\mathrm{Fe}-\mathrm{Mn} \text { oxides }}=+0.31 \pm 0.12 \%$, $1 \mathrm{SD}, \mathrm{n}=31$, data sources: Albarède, 2004; Little et al., 2014a). Fe-Mn crusts have previously been used as an analogue for the dispersed Fe-Mn oxide phases found throughout deep-sea pelagic sediments that are thought to be responsible for $\mathrm{Cu}$ removal from the ocean under normal 'oxic' marine conditions (Little et al., 2014a). Somewhat surprisingly, therefore, the data presented here suggest that $\mathrm{Cu}$ is removed from the ocean with a homogeneous isotopic composition (of about $+0.3 \%$ ) in all oceanic settings. Particularly surprising is the observation that, despite near quantitative removal of $\mathrm{Cu}$ from the sulphidic water columns of the Black Sea and Cariaco Basin (Jacobs et al., 1987; Haraldsson and Westerlund, 1991; Tankéré et al., 2001), bioauthigenic $\mathrm{Cu}$ isotope values from these two basins do not appear to record the $\delta^{65} \mathrm{Cu}$ of global mean seawater (at +0.6 to $+0.9 \%$; Vance et al., 2008; Thompson et al., 2014; Takano et al., 2014). We return to this observation in section 5.3.

\subsection{Bioauthigenic Cu in sediments: the isotopic counterpart to strong organic ligand-} bound $\mathrm{Cu}$ in the dissolved pool?

The vast majority of dissolved copper in all aqueous environments, from rivers and their estuaries (e.g., Dryden et al., 2004; Laglera and Van den Berg, 2003) to the open ocean den Berg, 1998; Moffett and Dupont, 2007; Jacquot and Moffett; 2015), is complexed to 
strong organic 'L1-type' ligands, which have binding constants $(\log K)$ in the range of 484 about 12-16. Both ab initio calculations (Sherman, 2013) and experiments (Bigalke et al., 2010; Ryan et al., 2014) indicate that strong organic ligands preferentially complex the heavy $\mathrm{Cu}$ isotope. Isotopically heavy $\mathrm{Cu}$ in the dissolved pool of rivers and the ocean has thus previously been hypothesised to result from preferential complexation of heavy $\mathrm{Cu}$ isotopes by these strong organic ligands (Vance et al., 2008; Thompson et al., 2014; Little et al., 2014b). Specifically, Vance et al. (2008) proposed that an equilibrium fractionation occurs directly between an organically complexed dissolved pool and the surface of scavenging particles (Vance et al., 2008). This scenario could also be invoked to explain the homogenous composition of the bioauthigenic $\mathrm{Cu}$ output flux observed here. The homogeneous composition of the oceanic $\mathrm{Cu}$ sink would, in this case, require open system steady-state fractionation with a fractionation factor $\left(\Delta=\delta^{65} \mathrm{Cu}_{\text {seawater }}-\delta^{65} \mathrm{Cu}_{\text {sinks }}\right)$ of $\sim 0.4 \%$ o between the aqueous and particulate phase.

Another plausible explanation for the homogeneous isotopic composition of the bioauthigenic $\mathrm{Cu}$ output flux, regardless of sedimentary redox state, is that an equilibrium isotopic fractionation exists between two species in the oxygenated aqueous phase. First, the organically complexed pool is highly soluble and enriched in heavy isotopes due to the strong binding environment provided by the strong organic ligands. Second, a particle reactive free $\mathrm{Cu}^{2+}$ pool, which is $\sim 0.4 \%$ lighter than the organic ligand-bound pool, is scavenged to particulates. Consistent with this scenario, Ryan et al. (2014) measured an isotopic fractionation factor $\Delta_{\text {ligand-free }}=0.44 \pm 0.40 \%(\mathrm{n}=3,2 \mathrm{SD})$ for a synthetic ligand (NTA) with a similar $\log \mathrm{K}$ to natural L1-type ligands $\left(\log \mathrm{K}_{\mathrm{NTA}}=14.4\right)$. In this case, where fractionation occurs between two $\mathrm{Cu}$ species in the aqueous phase, the nature of the particulate material to which $\mathrm{Cu}$ is scavenged is not relevant to the isotopic fractionation expressed. In the alternative scenario, where an equilibrium fractionation exists between the aqueous and particulate pools, there would need to be a near constant fractionation factor between aqueous $\mathrm{Cu}$ and all potential scavenging surfaces.

512 In either scenario, we hypothesise that scavenging by particulate organic matter plays a key 513 role in the water column. If this scavenging is a reversible process (e.g., Little et al., 2013), 514 and exchange continues with the dissolved pool as particles sink, then bottom water 515 isotope compositions will determine the isotope composition of particles when they reach 516 the sediment. In turn, this process may contribute to the homogeneity of the output flux, 
517 because deep waters exhibit less isotopic variability than the upper water column (Vance et

518 al., 2008; Takano et al., 2014, Thompson et al., 2014). Scavenging associated with Fe-Mn

519 cycling either in the water column or within the sediment is also likely to be important,

520 dependent on the setting. For example, active Fe-Mn oxide cycling close to the sediment-

521 water interface (e.g., San Nicolas, Santa Monica; Fig. 4) appears to enhance fixation of $\mathrm{Cu}$

522 with the bioauthigenic $\delta^{65} \mathrm{Cu}$ signature. Detailed spectroscopic and experimental work at

523 the mineral-organic-water interface increasingly supports the suggestion that organic and

524 oxide-bound phases are often inextricably linked (Lalonde et al., 2012; Johnson et al.,

525 2015; Tribovillard et al., 2015). In the case of an equilibrium isotope fractionation between

526 the dissolved phase and scavenging particles, this organic-oxide linkage may also

527 contribute to the isotopic homogeneity of the sedimentary sink.

\section{$5.3 \mathrm{Cu}$ in euxinic settings}

530

\subsubsection{The Cariaco Basin}

532 Near quantitative removal of $\mathrm{Cu}$ is observed from the euxinic water columns of both the

533 Black Sea and Cariaco Basin (Haraldsson and Westerlund, 1991; Tankéré et al., 2001;

534 Jacobs et al., 1987). Despite this removal from the water column, we do not observe

535 significantly elevated $\mathrm{Cu} / \mathrm{Al}$ in Cariaco Basin sediments (Fig. 3). There is, however, a shift

536 in $\delta^{65} \mathrm{Cu}$ ratios across the oxic-anoxic transition of the sediment core, from about +0.08 in

537 the oxic interval to $+0.20 \%$ in the euxinic interval (Fig. 3). Given the absence of

538 appreciable $\mathrm{Cu}$ enrichment, one possible explanation of this isotopic shift is a change in the

539 isotope composition of the local lithogenic background material. A change in the source of

540 lithogenic material to the Cariaco Basin on glacial-interglacial timescales has previously

541 been proposed based on $\mathrm{Al} / \mathrm{Ti}$ ratios. This change is hypothesised to reflect an increased

542 supply of Ti-rich dust from the Sahara during glacial periods, due to the more southerly

543 position of the ITCZ (Yarincik et al., 2000; Martinez et al., 2010). Alternatively, the data

544 and their uncertainties do permit the presence of a small amount of bioauthigenic $\mathrm{Cu}$ in the

545 euxinic interval. For example, assuming an $\mathrm{UCC} \mathrm{Cu} / \mathrm{Al}$ ratio of $3.5 \times 10^{-4}$ (Note: this ratio

546 is lower than that observed in the oxic interval), and $\delta^{65} \mathrm{Cu}_{\text {lith }}$ of $+0.08 \%$, the mean

547 calculated $\delta^{65} \mathrm{Cu}_{\text {auth }}$ for the euxinic portion of the sediment pile is $+0.66 \pm 0.25 \%$, similar

548 to that of modern open ocean seawater $\delta^{65} \mathrm{Cu}$ (at approximately $+0.7 \%$ ). There is an

549 indication, therefore, that bioauthigenic $\mathrm{Cu}$ deposited in sediments under Cariaco Basin-

550 type hydrographic conditions, where euxinia is primarily driven by productivity without 
551 strong basin restriction, may indeed record open ocean $\delta^{65} \mathrm{Cu}$. However, due to the very

552 low $\mathrm{Cu}$ enrichment observed (see also section 5.4), the local lithogenic background must

553 be carefully characterised and corresponding calculated $\delta^{65} \mathrm{Cu}_{\text {auth }}$ values should be

554 interpreted with caution.

555

\section{5.3.2 The Black Sea}

557 Copper is enriched by a factor of 3 to 7 in sediments from the Black Sea euxinic stations compared to those from the oxic stations (Fig. 2), such that the assumed composition of the local lithogenic background has very little impact on calculated $\delta^{65} \mathrm{Cu}_{\text {auth }}$ values (unlike in the Cariaco Basin). The Black Sea Cu isotope data therefore present us with a puzzle: given near quantitative removal from the water column, why are the $\delta^{65} \mathrm{Cu}$ values of euxinic Black Sea sediments not more similar to the isotopic composition of mean global seawater (at approximately $+0.7 \%$ ) ? Instead we find that the Black Sea bioauthigenic $\mathrm{Cu}$ has an isotope composition that is similar to the remainder of the reducing sedimentary dataset presented here (i.e., at around $+0.3 \%$ ).

One possibility is that the $\mathrm{Cu}$ isotope composition of the upper water column of the Mediterranean, which supplies the Black Sea through the shallow Bosporus Strait between 13 and $110 \mathrm{~m}$ water depth, is isotopically lighter than that of mean global seawater. Although $\mathrm{Cu}$ isotope data for seawater remains relatively sparse, the data that exist show limited variability in deep waters (at +0.6 to $0.9 \%$ : Vance et al., 2008; Takano et al., 2014; Thompson et al., 2014), but frequent small deviations towards lighter $\delta^{65} \mathrm{Cu}$ values in the upper water column (down to +0.4 to $0.5 \%$ : Takano et al., 2014). These relatively light surface values are most easily explained as the result of the deposition of aerosol dust, and the Mediterranean does receive a high mineral dust flux from the Sahara (Prospero, 1996). However, assuming modern inflow through the Bosporus Strait of $305 \mathrm{~km}^{3} \mathrm{yr}^{-1}$ (Özsoy and Ünlüata, 1997), and a surface water $\mathrm{Cu}$ concentration in the Mediterranean of 2.5 $\mathrm{nM}$ (Saager et al., 1993), the magnitude of the Mediterranean $\mathrm{Cu}$ source is about $7 \times 10^{7} \mathrm{~g}$ $\mathrm{yr}^{-1}$. The mean calculated authigenic $\mathrm{Cu}$ content of euxinic Black Sea sediments is $\sim 35$ ppm (ESM Table 1, range: 28 - 48 ppm). Given this value, and assuming a sediment density of $2.3 \mathrm{~g} \mathrm{~cm}^{-3}$, porosity of $80 \%$, anoxic basin area of $318,582 \mathrm{~km}^{-2}$ and a sedimentation rate of $0.0155 \mathrm{~cm} \mathrm{yr}^{-1}$, we calculate a $\mathrm{Cu}$ output flux to Black Sea euxinic sediments of $8 \times 10^{8} \mathrm{~g} \mathrm{yr}^{-1}$. This estimate is an order of magnitude higher than the estimated Mediterranean input flux. This imbalance is exacerbated by the fact that there is 
also a return flux to the Mediterranean from the surface Black Sea, representing a further substantial output of $\mathrm{Cu}$ from the basin. Hence, input of $\mathrm{Cu}$ from the Mediterranean alone can explain neither the enrichment nor the isotope signature of $\mathrm{Cu}$ observed in Black Sea sediments.

Rivers are the other likely key input of $\mathrm{Cu}$ to the Black Sea. The previously measured range of $\delta^{65} \mathrm{Cu}$ in a subset of relatively pristine global rivers is +0.02 to $+1.45 \%$, with a discharge-weighted average of $+0.68 \%$ (Vance et al., 2008). A measurement of Black Sea surface water of $+0.92 \%$ (Table 5; for sample collection and pre-concentration techniques, see Vance et al., 2016a) is within this riverine range and the range of published open ocean values. Though the isotope composition of the Black Sea surface ocean may be anthropogenically perturbed (e.g., Vance et al., 2016a), it seems unlikely - though we cannot definitively rule it out - that the relatively light isotopic composition of Black Sea sediments is a direct result of supply of isotopically light $\mathrm{Cu}$ from rivers.

A plausible explanation for the coherent isotopic composition of Black Sea sediments versus those from other marine settings is that the source of $\mathrm{Cu}$ to the restricted deep basin has, in fact, been subject to biogeochemical cycling similar to that envisaged in section 5.2. In this view, rivers supply isotopically heavy $\mathrm{Cu}$ to the oxic Black Sea surface layer. The transfer of this $\mathrm{Cu}$ to the deep euxinic portion of the basin is then mediated by the cycling of $\mathrm{Fe}$ and $\mathrm{Mn}$ and is associated with an isotopic fractionation between the aqueous and particulate phase similar to that which is proposed for the open ocean. Copper is complexed by organic ligands in Black Sea surface waters (Muller et al., 2001), and significant cycling of trace metals across the redoxcline has been hypothesised associated with the cycling of nanoparticulate Fe and Mn oxides at this depth (e.g., Lyons and Severmann, 2006; Little et al., 2015; Vance et al., 2016a). Specifically, nanoparticulate Fe and $\mathrm{Mn}$ oxides may form following their efflux from shelf sediments. These nanoparticulate phases can then be transported to the basin interior, where they are rereduced and dissolve: this is a version of the benthic redox shuttle (Severmann et al., 2008; Scholz et al., 2013; 2014). These Fe-Mn nanoparticles sorb other trace metals, forming a fine particle layer at the redoxcline that is rich in $\mathrm{Cu}, \mathrm{Ni}, \mathrm{Zn}$, and other metals (Tankéré et al., 2001). The scavenged $\mathrm{Cu}$, which need not be shelf-sediment sourced (as invoked for Fe and $\mathrm{Mn}$ ), is then released to the euxinic portion of the basin on reduction of the host Fe-Mn nanoparticles. Once there, sulphide minerals quantitatively re-scavenge the supplied $\mathrm{Cu}$. In 
619 this view, the 'shuttled' $\mathrm{Cu}$ would have an isotope composition of the bioauthigenic end member at $+0.3 \%$, i.e., approximately $+0.6 \%$ lighter than organically complexed, isotopically heavy, residual $\mathrm{Cu}$ in modern Black Sea surface waters.

623 Some support for this hypothesis comes from chemocline site 16B. Here, the upper two 624 data points (upper $4 \mathrm{~cm}$ of core) are slightly enriched in $\mathrm{Cu}$ and are distinctly isotopically 625 heavy at $+0.25 \%$ - similar to the bioauthigenic end member - compared to lithogenic-like

$626 \delta^{65} \mathrm{Cu}$ values observed deeper in the core (Fig. 2). The sediments at Station 16B were 627 deposited close to the position of the redoxcline at the time of coring, with dissolved oxygen at trace levels (Lyons, 1991). Enrichments in AVS (acid volatile sulphur) were evident in the black-grey, banded upper $2-4 \mathrm{~cm}$ of the core, compared to the increasingly bioturbated grey layers below. These observations have been interpreted to reflect an evolution from a more to a less oxygenated environment at this site (Lyons, 1991), i.e., a shoaling of the redoxcline, an assertion that is supported by the $\delta^{65} \mathrm{Cu}$ data presented here.

\subsection{The lithogenic dilution effect on $\mathrm{Cu}$ enrichment in marine sediments}

635

$636 \mathrm{Cu} / \mathrm{Al}$ data from the Cariaco Basin highlight that anoxia, and even euxinia, is not by itself 637 sufficient to produce strong authigenic $\mathrm{Cu}$ enrichments in sediments. Other data presented 638 here also illustrate this point clearly: the most reducing sedimentary environment of the 639 California Borderland basins is the Santa Barbara basin, which shows no authigenic $\mathrm{Cu}$ 640 enrichment and a lithogenic isotope composition. In Figure 7 we highlight one key reason for this, the control on $\mathrm{Cu}$ enrichment by sediment accumulation rate.

643 To isolate the role of lithogenic dilution of $\mathrm{Cu}$ contents in marine sediments, $\mathrm{Al}$ 644 accumulation rates $\left(\mathrm{S}_{\mathrm{Al}}\right)$ were calculated using estimates of sediment accumulation rates 645 from the literature, summarised in Table 1, and measured Al concentrations from this 646 study. Significant $\mathrm{Cu}$ enrichment is observed only at sites with an $\mathrm{S}_{\mathrm{Al}}$ of considerably less 647 than $0.1 \mathrm{mg} \mathrm{cm}^{-2} \mathrm{yr}^{-1}$ (Fig. 7). Plotting the $\mathrm{S}_{\mathrm{Al}}-\mathrm{Al} / \mathrm{Cu}$ relationship in this way allows a 648 quantitative assessment of the lithogenic dilution effect on $\mathrm{Cu}$ enrichment, via a box model 649 approach outlined by Jacobs et al. (1985; 1987). Full details of the box model are given in 650 the ESM. In brief, it is assumed that the flux of $\mathrm{Cu}$ (or any metal) to the sediment is 651 comprised of two components, the relative magnitude of which will determine metal 652 enrichment in the sediment: (1) a detrital (or lithogenic) flux defined by the $\mathrm{Cu} / \mathrm{Al}$ ratio of 
653 upper continental crust $(\mathrm{Cu} / \mathrm{Al})_{\text {lith }}$ and the accumulation rate of $\mathrm{Al}\left(\mathrm{S}_{\mathrm{Al}}\right)$ and (2) a

654 bioauthigenic flux derived from removal of dissolved $\mathrm{Cu}$ from the water column. We

655 assume that the latter may reflect either sulphidisation or uptake/scavenging by particulate

656 organic carbon and/or Fe-Mn oxides. The model is made up of an oxic surface ocean box

657 (Box 1) and an anoxic deep water box (Box 2), each of which are well mixed and exchange

658 on a timescale, $\mathrm{T}$, in ${\mathrm{m} \mathrm{yr}^{-1}}^{-1}$ ESM Fig. 1). The authigenic enrichment of a metal, $\mathrm{S}_{\text {enrich, }}$

659 then depends on three parameters: (1) $\mathrm{S}_{\mathrm{Al}}$; (2) the concentration difference between oxic

660 box 1 and anoxic box 2, $\mathrm{C}_{1}-\mathrm{C}_{2}$; and (3) the timescale of mixing, $\mathrm{T}$. We apply this model to

661 the Cariaco Basin (directly following Jacobs et al., 1987) and to the Black Sea. Parameters

662 used are given in Table 6. Note that $\mathrm{T}$ is related to the residence time of water in the deep

663 box, $\tau_{2}$, by the thickness of this box, $\mathrm{z}_{2}: \mathrm{T}=\mathrm{z}_{2} \tau_{2}{ }^{-1}$. This mixing timescale is somewhat

664 slower in the Black Sea $\left(\sim 5 \mathrm{~m} \mathrm{yr}^{-1}\right)$ than in the Cariaco Basin $\left(\sim 11 \mathrm{~m} \mathrm{yr}^{-1}\right)$, due to the

665 longer residence time of Black Sea deep waters (Table 6). In addition, the parameter $\mathrm{C}_{1}-\mathrm{C}_{2}$

666 in the Black Sea (6.5 nM; Tankéré et al., 2001) is quadruple that of the Cariaco Basin (1.1

$667 \mathrm{nM}$, Jacobs et al., 1987), due to the relatively low Cu concentration of the South Atlantic

668 source waters that flow into the Cariaco Basin. The results of the model are plotted as

669 dashed (Black Sea model parameters) and solid (Cariaco Basin model parameters) black

670 lines in Figure 7 for the full range of $\mathrm{S}_{\mathrm{Al}}$ values observed for sites in this study. Agreement

671 between the model and site-averaged $\mathrm{Cu} / \mathrm{Al}$ values is observed for the two euxinic sites.

672

673 This simple 2-box model is not directly applicable to open margin sites, like the Peru and

674 Magdalena margin regions, and we have insufficient data to perform a detailed analysis for

675 the other basinal sites included here. We can, however, find parameters that give

676 reasonable results, even for the exceptional Peru margin site (dotted black line, Fig. 7). For

677 this model we assume a removal term of $\mathrm{Cu}$ into particulate organic matter of $2 \mathrm{nM}$, over a

678 depth range of $100 \mathrm{~m}$, and with a very short water residence time (1 year). This result

679 should be considered illustrative only, nevertheless, the model gives clear mechanistic

680 insight into lithogenic dilution of the bioauthigenic flux of $\mathrm{Cu}$.

681 
Figure 7. $\mathrm{Al}$ accumulation rate $\left(\mathrm{S}_{\mathrm{Al}}\right)$ versus site average $\mathrm{Cu} / \mathrm{Al}$. Black lines show superimposed box model results (solid - Cariaco Basin; dashed - Black Sea; dotted - Peru margin; see Table 6 for selected model parameters and ESM for additional model details). All symbols are the same as in Figs $2-5$. Coloured dotted ranges in $\mathrm{S}_{\mathrm{Al}}$ reflect published range in sediment accumulation rates for nearby sites compiled from the literature (see Table 1). Error bars on $\mathrm{Cu} / \mathrm{Al}$ ratios and $\mathrm{S}_{\mathrm{Al}}$ (where sediment accumulation rates for the 689

690 same sediment core have been published) reflect $2 \mathrm{SD}$ variability for the core.

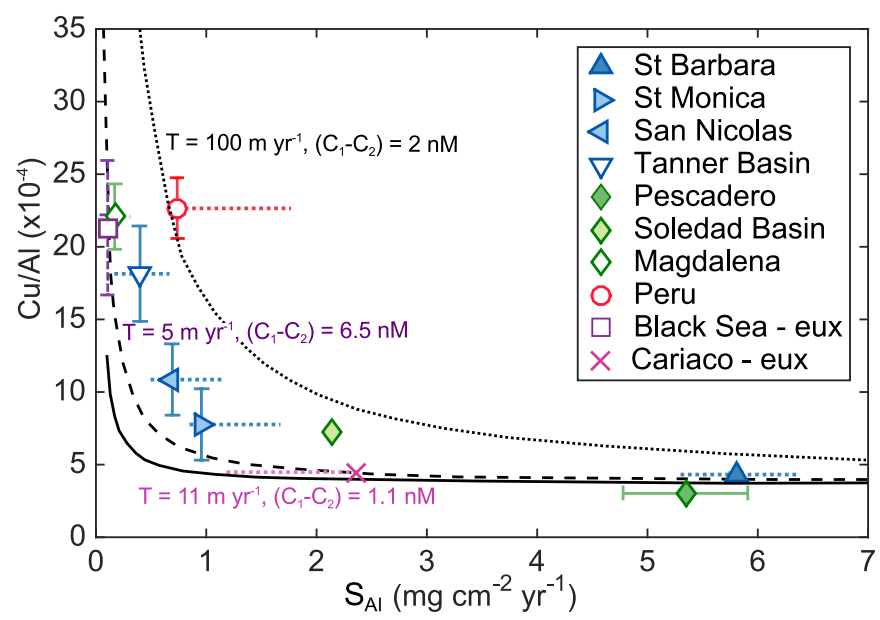

691

692

One of the motivations for this study was to place constraints on the modern reducing sedimentary sink for $\mathrm{Cu}$ and $\mathrm{Cu}$ isotopes. A first order approximation of the net flux of $\mathrm{Cu}$ into continental margin settings can be calculated using an estimate of marine organic $\mathrm{C}$ burial rate and the slope of the $\mathrm{C}_{\text {org }} / \mathrm{Al}$ versus $\mathrm{Cu} / \mathrm{Al}$ relationship for continental margin sites. This slope is $0.00041 \mathrm{~g} \mathrm{Cu} / \mathrm{g} \mathrm{C}$ (ESM Fig. 3; data from this study and Böning et al., 2012). Smith et al. (2015) calculate a global marine $\mathrm{C}_{\text {org }}$ burial rate of $\sim 170 \times 10^{12} \mathrm{~g} \mathrm{C} \mathrm{yr}^{-1}$. Together, this equates to an organic $\mathrm{C}$ associated $\mathrm{Cu}$ burial flux of $\sim 11 \times 10^{8} \mathrm{~mol} \mathrm{yr}^{-1}$. This value is an order of magnitude higher than an estimate for the role of continental margin sediments based on Mo as an analogue (Little et al., 2015) and slightly above the range of $\mathrm{Cu}$ removal estimates to oxic pelagic sedimentary settings, estimated at $1.6-9.7 \times 10^{8}$ mol/yr (Little et al., 2014a; Little et al., 2015). The calculation excludes the additional flux of $\mathrm{Cu}$ to euxinic sediments via the redox-shuttle mechanism proposed for the Black Sea, which is quantitatively small today $\left(\sim 0.5 \times 10^{8} \mathrm{~mol} / \mathrm{yr}\right.$; Little et al., 2015), but may have been more significant in the past. Given a total ocean $\mathrm{Cu}$ budget of $4.2 \times 10^{12}$ moles (Little et al., 2014a) and the sum of the three output fluxes (pelagic, continental margin, redox- 
shuttle), we calculate a $\mathrm{Cu}$ oceanic residence time (where $\tau=$ total inventory of element $\div$ annual total input or output flux of element) of $2000-3200$ years.

713 Together, the continental margin and pelagic $\mathrm{Cu}$ sinks sum to approximately twice the total 714 estimated riverine and dust input flux of Little et al. (2014a) $\left(6.5-9.2 \times 10^{8} \mathrm{~mol} / \mathrm{yr}\right)$. In 715 addition, all sedimentary sinks for $\mathrm{Cu}$ are isotopically light (at about $+0.3 \%$ ) compared to

716 the isotope composition of the combined riverine and dust flux (at approximately $+0.6 \%$,

717 Little et al., 2014a). If the $\mathrm{Cu}$ oceanic budget is at steady state, these observations require

718 either an additional sink that is isotopically heavy or (a) further source(s) that is/are

719 isotopically light. Given the flux imbalance (i.e., known output fluxes $>>$ known input

720 fluxes) and the fact that the major output fluxes have now been characterised, a missing

721 input flux appears more probable. Mass balance implies this missing source be $\sim 9 \times 10^{8}$

$722 \mathrm{~mol} / \mathrm{yr}$ and have an isotope composition of $\sim 0 \%$, illustrated schematically in Figure 8.

724 Figure 8. Schematic illustrating the updated oceanic budget of $\mathrm{Cu}$ and $\mathrm{Cu}$ isotopes (after 725 Little et al., 2014a; 2015; this study). Arrows are scaled by flux magnitude and labelled 726 and coloured by isotope composition (yellow represents the isotopically light components, blue the isotopically heavier components, and green is intermediate). The projected missing source size and isotope composition is shown as a dashed arrow to the left of the figure (see text for details). For reference to colours, please see online version of this 730 figure.

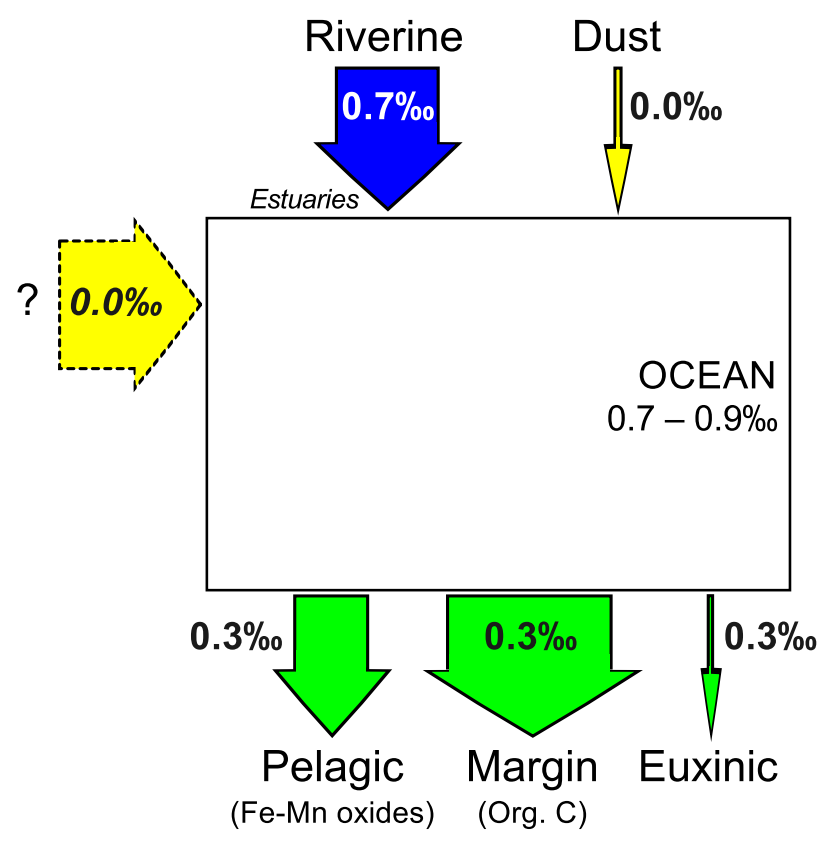

733 The main input of $\mathrm{Cu}$ to the modern ocean has typically been assumed to be the dissolved 734 phase in rivers (e.g., Little et al., 2014a). Two independent estimates put this riverine 
dissolved flux at $6-9 \times 10^{8} \mathrm{~mol} / \mathrm{yr}$ (Gaillardet et al., 2003; Vance et al., 2008). This dissolved riverine flux is isotopically heavy, with a discharge-weighted riverine average $\delta^{65} \mathrm{Cu}$ of $+0.68 \%$ (Vance et al., 2008). These estimates assume conservative behaviour of $\mathrm{Cu}$ during estuarine mixing, as observed, for example, for two major river systems: the Chiang Jiang and the Amazon (Boyle et al., 1982; Edmond et al., 1985). However, nonconservative behaviour of $\mathrm{Cu}$ has also been observed in a spectrum of estuarine systems (e.g., Morris et al., 1978; Windom et al., 1983; Ackroyd et al., 1986). Furthermore, the dissolved flux of $\mathrm{Cu}$ accounts for only $\sim 20 \%$ of the total riverine flux of $\mathrm{Cu}$ to the ocean, with the remainder delivered in particulate form (e.g., Martin and Meybeck, 1979). The partial dissolution of riverine particulates has recently been suggested as a significant oceanic source of several metals (e.g., Oelkers et al., 2012; Jones et al., 2012; 2014). Vance et al. (2008) report isotopically light $\mathrm{Cu}$ in the particulate phase of one small river system in the U.K, which is complementary to the heavy dissolved pool. Partial remobilisation of isotopically light riverine particulates, whether lithogenic or other (e.g. terrestrial organic matter) particles, may therefore provide one possible isotopically light flux of $\mathrm{Cu}$ to the ocean. Release could be envisaged in, e.g., anoxic estuarine environments, or further out in continental margin or open ocean settings. By analogy, release of neodymium $(\mathrm{Nd})$ from the lithogenic phase has been hypothesised in continental margin settings (e.g., Jeandel et al., 2007; Pearce et al., 2013; Abbott et al., 2015; Abbott et al., 2016).

The natural (non-anthropogenic) dust flux of $\mathrm{Cu}$ to the ocean appears to be isotopically unfractionated from the lithogenic $\mathrm{Cu}$ source (at $\sim 0 \%$ ), based on analysis of the waterleachable fraction of aerosols and loess particles (Little et al., 2014a; Dong et al., 2013). The magnitude of this natural dust flux has been calculated by two studies, one data-driven (Little et al., 2014a) and one model-based (Takano et al., 2014). In the data-driven approach, the flux is calculated based on a model of global dust deposition (Jickells et al., 2005), an estimate of the Cu concentration in UCC (35ppm; Rudnick and Gao, 2003), and an estimate of mineral dust solubility (27\%; Desboeufs et al., 2005), yielding a $\mathrm{Cu}$ flux of $0.5 \times 10^{8} \mathrm{~mol} / \mathrm{yr}$ (Little et al., 2014a). In the model-derived approach, Takano et al. (2014) invoked a much larger dust flux, at $\sim 10 \times 10^{8} \mathrm{~mol} / \mathrm{yr}$, in order to balance their steady state model-derived output flux of $17 \times 10^{8} \mathrm{~mol} / \mathrm{yr}$. The latter value is, itself, in line with the sum of the pelagic and continental margin sinks proposed here. Assuming a lithogenic isotope composition (0\%) for their postulated dust flux, Takano et al. (2014) further 
calculate that the $\mathrm{Cu}$ isotope composition of the output flux should be $+0.3 \%$ o (Takano et al., 2014), also consistent with results in this study. Nevertheless, we consider a very large dust flux to be rather unlikely, due in part to the low solubility of $\mathrm{Cu}$ in dust (e.g., Desboeufs et al., 2005; Sholkovitz et al., 2010). Even if mineral dust were completely soluble - for example, if solubility is enhanced by the presence of organic ligands (as suggested for Fe; Fishwick et al., 2014) - the maximum $\mathrm{Cu}$ input flux possible based on an estimate of global mineral dust deposition and the $\mathrm{Cu}$ concentration in UCC is five times lower than that required by Takano et al. (2014), at $2.0 \times 10^{8} \mathrm{~mol} / \mathrm{yr}$.

Of other possible inputs, a hydrothermal $\mathrm{Cu}$ source has to date been assumed to be globally insignificant due its to efficient removal close to the vent (e.g., Trocine and Trefry, 1988; German et al., 1991; 2002). Scavenging within the Atlantic TAG hydrothermal plume indicates that hydrothermal activity may in fact be a net sink of $\mathrm{Cu}$, at least in certain environments (Jacquot and Moffett, 2015; Roshan and Wu, 2015). However, recent water column data for a range of trace elements and their isotopes, collected as part of the international GEOTRACES program, has highlighted significant basin scale heterogeneity in the iron $(\mathrm{Fe})$ and zinc $(\mathrm{Zn})$ hydrothermal flux, indicating that this potential source should be re-evaluated (Resing et al., 2015; Roshan et al., 2016). Sander and Koschinsky (2011) suggest that organic complexation may be one means to stabilise metals from hydrothermal vent sources in the dissolved phase. Primary hydrothermal fluxes are likely to have a lithogenic $\mathrm{Cu}$ isotope composition (at $\sim 0 \%$ ), though these may be subject to considerable secondary isotope fractionation effects resulting from sulphide precipitation, organic complexation, and/or scavenging to oxide phases.

Benthic fluxes have long been considered to play a role in the water column distribution of dissolved $\mathrm{Cu}$ (e.g., Boyle et al., 1977). In terms of oceanic mass balance, there are two ways in which such a benthic flux can be envisaged, which differ according to the solid phase from which the $\mathrm{Cu}$ is released to bottom waters. The first requires that $\mathrm{Cu}$ be released from external sources, either via rivers (as discussed above), or hydrothermal particulates. This possibility would then represent a true new source of $\mathrm{Cu}$ to the ocean and might be expected to be isotopically light if lithogenic or hydrothermal material is the source. The second type of benthic flux involves re-release to bottom waters of bioauthigenic $\mathrm{Cu}$ (i.e., $\mathrm{Cu}$ from the water column). This process may occur in porewaters of suboxic sediments, where suboxic denotes negligible dissolved oxygen and sulphide. 
803 Under these conditions, $\mathrm{Cu}$ carrier phases (Fe-Mn oxides, organic matter) are reduced, and

804 Cu could diffuse into bottom water (Shaw et al., 1990; Elderfield et al., 1981; Heggie et al., 805 1987; Klinkhammer, 1980; Sawlan and Murray, 1983). This process may be aided by

806 complexation to strong organic ligands in porewaters (Skrabal et al., 1997; 2000; Shank et 807 al., 2004a; 2004b). In itself, this process does not constitute a true new source of $\mathrm{Cu}$ to the 808 oceans, because the $\mathrm{Cu}$ that is returned to the water column came from the water column 809 i.e., the $\mathrm{Cu}$ is recycled. Note that any such recycling is implicit in the calculation of the 810 organic $\mathrm{C}$ burial-associated $\mathrm{Cu}$ flux (i.e., this is a net flux). This recycling could, however, 811 be accompanied by an isotopic effect, if isotope fractionation occurs in the sediment pile.

812 An isotopically light signature for such a source would require preferential retention of

813 heavy $\mathrm{Cu}$ isotopes in the solid phase. This direction of fractionation would not be

814 consistent, however, with what would be predicted based on organic complexation of $\mathrm{Cu}$ in 815 pore waters. This process is likely to favour retention of heavy $\mathrm{Cu}$ isotopes in the soluble 816 phase, with the removal of light $\mathrm{Cu}$ isotopes to particles.

817

818 Ultimately, we suggest that better resolution of the $\mathrm{Cu}$ isotope budget requires future 819 studies focussing on: (1) an improved evaluation of the diagenetic processing of $\mathrm{Cu}$ and its 820 isotopes, (2) the fate and isotopic signature of hydrothermally sourced $\mathrm{Cu}$, and (3) the 821 behaviour of continent-derived particulate $\mathrm{Cu}$ in the marine environment, both in estuaries 822 and more distally.

\section{Conclusions and Outlook}

826

827 This study presents a $\mathrm{Cu}$ isotope dataset for recent organic rich sediments from a range of

828 low oxygen and reducing sedimentary environments. The data indicate that the modern

829 bioauthigenic (i.e., non-lithogenic) oceanic $\mathrm{Cu}$ output flux is isotopically homogeneous

830 across many sedimentary environments - at about $+0.3 \%$. This value is significantly

831 lighter than the isotope composition of the open oceans, at +0.6 to $+0.9 \%$. We suggest that

832 the homogeneous isotopic composition of the $\mathrm{Cu}$ output flux reflects either (1) an

833 equilibrium isotope fractionation between two species in the dissolved phase, with an

834 isotopically heavy dissolved pool complexed by strong organic ligands and a particle

835 reactive, isotopically light free $\mathrm{Cu}^{2+}$ pool, or (2) an equilibrium isotope fractionation

836 directly between the organically complexed dissolved pool and the particulate phase. In the 
837 latter scenario all particulates would be required to exhibit the same fractionation from the

838 dissolved pool. In either case, continuous reversible exchange between sinking particulates 839 and the dissolved pool, all the way down through the water column, may contribute to the 840 homogeneity of the output flux.

842 Unexpectedly, highly $\mathrm{Cu}$ enriched euxinic Black Sea sediments (with $\delta^{65} \mathrm{Cu}_{\text {auth }}$ of $+0.3 \%$ )

843 do not record the $\mathrm{Cu}$ isotope signature of the open ocean (at around +0.6 to $+0.9 \%$ ),

844 despite near quantitative removal of $\mathrm{Cu}$ from the water column. We hypothesize that this 845 signature reflects active Fe-Mn cycling at the Black Sea redoxcline, with shuttling of 846 isotopically 'bioauthigenic' $\mathrm{Cu}$ (i.e., at $+0.3 \%$ ) to the restricted deep basin where it is 847 removed to sediment via sulphide precipitation. A similar process, albeit on a smaller 848 length-scale, likely also occurs at the sediment-water interface of suboxic to anoxic 849 continental margin sediments (e.g., San Nicolas Basin) and is also evident in the modern850 day near-chemocline station of the Black Sea (Station 16B). In all cases, we envisage that 851 an isotopically heavy pool of $\mathrm{Cu}$ is retained in the dissolved phase via complexation to 852 strong organic ligands.

854 Low oxygen conditions alone are not sufficient to generate strong enrichment of $\mathrm{Cu}$ in marine sediments. Variability in the dataset presented here can be explained to first order in terms of dilution of the bioauthigenic signature (at about $+0.3 \%$ ) with lithogenic material (at $\sim 0 \%$ ), and the lithogenic sedimentary accumulation rate is a strong control on the presence or absence of the bioauthigenic $\delta^{65} \mathrm{Cu}$ signature in sediments.

860 We note that all characterised sinks for $\mathrm{Cu}$ in the modern ocean are isotopically light (at 861 about $+0.3 \%$ ) relative to the current best estimate for the input flux (at about $+0.6 \%$; Little 862 et al., 2014a). This disparity indicates the presence of an as yet unidentified isotopically 863 light source, of approximately lithogenic composition ( $\sim \%$; Fig. 8). Dust is one such

864 possible light source, as previously suggested by Takano et al. (2014). We suggest two 865 other possible light sources of $\mathrm{Cu}$ : (1) hydrothermal input, (2) partial dissolution of 866 continentally derived particulates. Distinguishing among these three possible input fluxes requires future detailed research.

869 Finally, our findings, along with those of several previous studies, indicate that strong 870 organic ligands play a key role in the modern biogeochemical cycle of $\mathrm{Cu}$ and $\mathrm{Cu}$ isotopes. 
871 This role must be fully considered in future studies seeking to apply $\mathrm{Cu}$ isotopes in the

872 rock record as a paleoceanographic tracer.

873

874

875

876

877

878

879

880

881

882

883

884

885

886

887

888

889

890

891

892

893

894

895

896

897

898

899

900

901

902

903

904

905

906

907

\section{Acknowledgments}

The authors would like to thank three anonymous reviewers and the associate editor R. James for comments that significantly improved the manuscript. Little is supported by a Leverhulme early career fellowship at Imperial. Isotopic measurements at Bristol were supported by a NERC-funded PhD studentship NE/H525111/1 to Little. The ETH Zürich project work was supported by Swiss National Science Foundation Project 200021_153087 to Vance. Continental margin sediment sample collection was supported by multiple US NSF grants to McManus including OCE-0624777 and OCE-0219651. McManus was also supported by U.S. National Science Foundation grant OCE-1657832. Lyons is grateful for support from the NASA Astrobiology Institute and the NSF FESD and ELT programs. We thank William Berelson and Gary Klinkhammer for their contributions to cruises where some of these samples were collected, and Chris Coath and Corey Archer for facilitating the smooth running of clean labs and mass spectrometers in Bristol and Zürich.

\section{References}

Abbott, A. N., Haley, B. A., and McManus, J. (2015). Bottoms up: Sedimentary control of the deep North Pacific Ocean's \&Nd signature. Geology 43(11), 1035-1035.

Abbott, A. N., Haley, B. A., and McManus, J. (2016). The impact of sedimentary coatings on the diagenetic Nd flux. Earth Planet. Sci. Lett. 449, 217-227.

Ackroyd, D. R., Bale, A. J., Howland, R. J. M., Knox, S., Millward, G. E., and Morris, A. W. (1986). Distributions and behaviour of dissolved $\mathrm{Cu}, \mathrm{Zn}$ and $\mathrm{Mn}$ in the Tamar Estuary. Estuar. Coast. Shelf S. 23(5), 621-640.

Albarède, F. (2004) The stable isotope geochemistry of copper and zinc. Rev. Mineral. Geochem. 55(1), 409-427.

Algeo, T., and Lyons, T. (2006) Mo-total organic carbon covariation in modern anoxic marine environments: Implications for analysis of paleoredox and paleohydrographic conditions. Paleoceanography 21(1), PA1016.

Algeo, T. J., and Maynard, J. B. (2004) Trace-element behavior and redox facies in core shales of Upper Pennsylvanian Kansas-type cyclothems. Chem. Geol. 206(3-4), 289318 . 
Archer C. and Vance D. (2004) Mass discrimination correction in multiple-collector plasma source mass spectrometry: an example using $\mathrm{Cu}$ and $\mathrm{Zn}$ isotopes. J. Anal. At. Spectrom. 19(5), 656-665.

Arnold, G. L., Anbar, A. D., Barling, J., and Lyons, T. W. (2004) Molybdenum isotope evidence for widespread anoxia in mid-Proterozoic oceans. Science 304(5667), 87-90.

Asael, D., Matthews, A., Bar-Matthews, M., and Halicz, L. (2007). Copper isotope fractionation in sedimentary copper mineralization (Timna Valley, Israel). Chem. Geol. 243(3), 238-254.

Barling, J., and Anbar, A. D. (2004). Molybdenum isotope fractionation during adsorption by manganese oxides. Earth Planet. Sci. Lett. 217(3), 315-329.

Barling, J., Arnold, G. L., and Anbar, A. D. (2001). Natural mass-dependent variations in the isotopic composition of molybdenum. Earth Planet. Sci. Lett. 193(3), 447-457.

Berelson, W. M. (1991). The flushing of two deep-sea basins, southern California borderland. Limnol. Oceanogr. 36(6), 1150-1166.

Berelson, W. M., Hammond, D. E., and Johnson, K. S. (1987). Benthic fluxes and the cycling of biogenic silica and carbon in two southern California borderland basins. Geochim. Cosmochim. Acta 51(6), 1345-1363.

Berelson, W. M., McManus, J., Coale, K. H., Johnson, K. S., Kilgore, T., Burdige, D., and Pilskaln, C. (1996). Biogenic matter diagenesis on the sea floor: A comparison between two continental margin transects. J. Mar Res. 54(4), 731-762.

Berelson, W. M., Prokopenko, M., Sansone, F. J., Graham, A. W., McManus, J., and Bernhard, J. M. (2005). Anaerobic diagenesis of silica and carbon in continental margin sediments: discrete zones of TCO2 production. Geochim. Cosmochim. Acta 69(19), 4611-4629.

Bermin J., Vance D., Archer C. and Statham P. J. (2006) The determination of the isotopic composition of $\mathrm{Cu}$ and $\mathrm{Zn}$ in seawater. Chem. Geol. 226(3-4), 280-297.

Bigalke, M., Weyer, S., and Wilcke, W. (2010). Copper isotope fractionation during complexation with insolubilized humic acid. Environ. Sci. Technol. 44(14), 54965502 .

Böning, P., Brumsack, H., Böttcher, M. E., Schnetger, B., Kriete, C., Kallmeyer, J., and Borchers, S. L. (2004) Geochemistry of Peruvian near-surface sediments. Geochim. Cosmochim. Acta 68(21), 4429-4451.

Böning, P., Cuypers, S., Grunwald, M., Schnetger, B., and Brumsack, H. J. (2005). Geochemical characteristics of Chilean upwelling sediments at 36 S. Mar. Geol. 220(1), 1-21.

Böning, P., Fröllje, H., Beck, M., Schnetger, B., and Brumsack, H. J. (2012). Underestimation of the authigenic fraction of $\mathrm{Cu}$ and $\mathrm{Ni}$ in organic-rich sediments. Mar. Geol. 323, 24-28.

Boyle, E. A., Sclater, F. R., and Edmond, J. M. (1977). The distribution of dissolved copper in the Pacific. Earth Planet. Sci. Lett. 37(1), 38-54.

Bruland, K. W. (1980). Oceanographic distributions of cadmium, zinc, nickel, and copper in the North Pacific. Earth Planet. Sci. Lett. 47(2), 176-198. 
960

961

962

963

964

965

966

967

968

969

970

971

972

973

974

975

976

977

978

979

980

981

982

983

984

985

986

987

988

989

990

991

992

Bruland K. W. and Lohan M. C. (2003) Controls of Trace Metals in Seawater. Pergamon, Oxford, 23-47.

Bruland K. W., Orians K. J. and Cowen J. P. (1994) Reactive trace metals in the stratified central North Pacific. Geochim. Cosmochim. Acta 58(15), 3171-3182.

Bruland, K. W., Koide, M., and Goldberg, E. D. (1974). The comparative marine geochemistries of lead 210 and radium 226. J. Geophys. Res. 79(21), 3083-3086.

Bruland, K. W., Franks, R. P., Landing, W. M., and Soutar, A. (1981). Southern California inner basin sediment trap calibration. Earth Planet. Sci. Lett. 53(3), 400-408.

Brumsack H. (2006) The trace metal content of recent organic carbon-rich sediments: implications for cretaceous black shale formation. Palaeogeogr. Palaeoclimatol. Palaeoecol. 232(2), 344-361.

Buesseler, K. O., and Benitez, C. R. (1994). Determination of mass accumulation rates and sediment radionuclide inventories in the deep Black Sea. Deep Sea Res. Pt I 41(11), $1605-1615$.

Calvert S. and Pedersen T. (1993) Geochemistry of recent oxic and anoxic marine sediments: implications for the geological record. Mar. Geol. 113(1), 67-88.

Canfield, D. E. (1998). A new model for Proterozoic ocean chemistry. Nature 396(6710), $450-453$.

Chong, L. S., Prokopenko, M. G., Berelson, W. M., Townsend-Small, A., and McManus, J. (2012). Nitrogen cycling within suboxic and anoxic sediments from the continental margin of Western North America. Mar. Chem. 128, 13-25.

Coale K. H. and Bruland K. W. (1988) Copper complexation in the Northeast Pacific. Limnol. Oceanogr. 33(5), 1084-1101.

Coale, K. H., and Bruland, K. W. (1990). Spatial and temporal variability in copper complexation in the North Pacific. Deep Sea Res. 37(2), 317-336.

Conway, T. M., and John, S. G. (2014). Quantification of dissolved iron sources to the North Atlantic Ocean. Nature 511(7508), 212-215.

Dean, W. E., Piper, D. Z., and Peterson, L. C. (1999) Molybdenum accumulation in Cariaco Basin sediment over the past 24 k.y.: A record of water-column anoxia and climate. Geology 27(6), 507-510.

Desboeufs K., Sofikitis A., Losno R., Colin J. and Ausset P. (2005) Dissolution and solubility of trace metals from natural and anthropogenic aerosol particulate matter. Chemosphere 58(2), 195-203.

Deutsch, C., Berelson, W., Thunell, R., Weber, T., Tems, C., McManus, J., Crusius, J., Ito, T., Baumgartner, T., Ferreira, V., Mey, J., and van Geen, A. (2014). Centennial changes in North Pacific anoxia linked to tropical trade winds. Science 345(6197), 665-668.

Dong, S., Weiss, D. J., Strekopytov, S., Kreissig, K., Sun, Y., Baker, A. R., and Formenti, $\mathrm{P}$. (2013). Stable isotope ratio measurements of $\mathrm{Cu}$ and $\mathrm{Zn}$ in mineral dust (bulk and size fractions) from the Taklimakan Desert and the Sahel and in aerosols from the eastern tropical North Atlantic Ocean. Talanta 114, 103-109.

Douville, E., Charlou, J.-L., Oelkers, E.H., Bienvenu, P., Jove Colan, C.F., Donval, J.P., Fouquet, Y., Prieur, D. and Appriou, P. (2002). The Rainbow vent fluids (36 ${ }^{\circ} 14^{\prime} \mathrm{N}$, 
MAR): the influence of ultramafic rocks and phase separation on trace metal content in Mid-Atlantic Ridge hydrothermal fluids. Chem. Geol. 184, 37-48.

Dryden, C. L., Gordon, A. S., and Donat, J. R. (2004). Interactive regulation of dissolved copper toxicity by an estuarine microbial community. Limnol. Oceanogr. 49(4), 11151122.

Ehrlich, S., Butler, I., Halicz, L., Rickard, D., Oldroyd, A., and Matthews, A. (2004). Experimental study of the copper isotope fractionation between aqueous $\mathrm{Cu}$ (II) and covellite, CuS. Chemical Geology 209(3), 259-269.

Elderfield, H. (1981). Metal-organic associations in interstitial waters of Narragansett Bay sediments. Am. J. Sci. 281(9), 1184-1196.

Elderfield, H., Luedtke, N., McCaffrey, R. J., and Bender, M. (1981) Benthic flux studies in Narragansett Bay. Am. J. Sci. 281(6), 768-787.

Elrod, V. A., Johnson, K. S., and Coale, K. H. (1991). Determination of subnanomolar levels of iron (II) and total dissolved iron in seawater by flow injection and analysis with chemiluminescence detection. Anal. Chem. 63(9), 893-898.

Emerson, S. R., and Huested, S. S. (1991). Ocean anoxia and the concentrations of molybdenum and vanadium in seawater. Mar. Chem. 34(3-4), 177-196.

Emery, K. O. (1954). General geology of the offshore area, southern California. Bull. Calif. Div. Mines Geol. 170, 107-111.

Emery, K. O. (1960). Basin plains and aprons off southern California. J. Geology, 464479.

Emeis, K. C., Whelan, J. K., and Tarafa, M. (1991) Sedimentary and geochemical expressions of oxic and anoxic conditions on the Peru shelf. Geological Society, London, Special Publications 58(1), 155-170.

Eppley, R. W. (1992). Chlorophyll, photosynthesis and new production in the Southern California Bight. Prog. Oceanogr. 30(1-4), 117-150.

Finney, B., and Huh, C. A. (1989). High resolution sedimentary records of heavy metals from the Santa Monica and San Pedro Basins, California. Marine Poll. Bull. 20(4), $181-187$.

Fishwick, M. P., P. N. Sedwick, M. C. Lohan, P. J. Worsfold, K. N. Buck, T. M. Church, and S. J. Ussher (2014), The impact of changing surface ocean conditions on the dissolution of aerosol iron, Global Biogeochem. Cycles 28, 1235-1250.

Francois R. (1988) A study on the regulation of the concentrations of some trace metals ( $\mathrm{Rb}, \mathrm{Sr}, \mathrm{Zn}, \mathrm{Pb}, \mathrm{Cu}, \mathrm{V}, \mathrm{Cr}, \mathrm{Ni}, \mathrm{Mn}$ and $\mathrm{Mo}$ ) in Saanich Inlet Sediments, British Columbia, Canada. Mar. Geol. 83(1), 285-308.

Fujii, T., Moynier, F., Abe, M., Nemoto, K., and Albarède, F. (2013). Copper isotope fractionation between aqueous compounds relevant to low temperature geochemistry and biology. Geochim. Cosmochim. Acta 110, 29-44.

Gaillardet J., Viers J. and Dupré B. (2003) Trace elements in river waters. Treatise Geochem. 5, 225-272.

German C. R., Campbell A. C. and Edmond J. M. (1991) Hydrothermal scavenging at the mid-Atlantic ridge: modification of trace element dissolved fluxes. Earth Planet. Sci. Lett. 107(1), 101-114. 
German C. R., Colley S., Palmer M. R., Khripounoff A. and Klinkhammer G. P. (2002) Hydrothermal plume-particle fluxes at $13 \mathrm{~N}$ on the East Pacific Rise. Deep Sea Res. 49(11), 1921-1940.

Goni, M. A., Aceves, H. L., Thunell, R. C., Tappa, E., Black, D., Astor, Y., ... and MullerKarger, F. (2003). Biogenic fluxes in the Cariaco Basin: a combined study of sinking particulates and underlying sediments. Deep Sea Res. Pt I. 50(6), 781-807.

Gordon, A. S., Dyer, B. J., Kango, R. A., and Donat, J. R. (1996). Copper ligands isolated from estuarine water by immobilized metal affinity chromatography: temporal variability and partial characterization. Mar. Chem. 53(3), 163-172.

Haraldsson, C., and Westerlund, S. (1991). Total and suspended cadmium, cobalt, copper, iron, lead, manganese, nickel, and zinc in the water column of the Black Sea. In Black Sea Oceanography (pp. 161-172). Springer Netherlands.

Hartnett, H. E., Keil, R. G., Hedges, J. I., and Devol, A. H. (1998). Influence of oxygen exposure time on organic carbon preservation in continental margin sediments. Nature 391(6667), 572-575.

Haug, G. H., Pedesen, T. F., Sigman, D. M., Calvert, S. E., Nielsen, B., and Peterson, L. C. (1998) Glacial/interglacial variations in production and nitrogen fixation in the Cariaco Basin during the last 580 kyr. Paleoceanography 13(5), 427-432.

Heggie, D., Klinkhammer, G., and Cullen, D. (1987). Manganese and copper fluxes from continental margin sediments. Geochim. Cosmochim. Acta 51(5), 1059-1070.

Huh, C. A., Small, L. F., Niemnil, S., Finney, B. P., Hickey, B. M., Kachel, N. B., ... and Williams, P. M. (1990). Sedimentation dynamics in the Santa Monica-San Pedro Basin off Los Angeles: radiochemical, sediment trap and transmissometer studies. Cont. Shelf Res. 10(2), 137-164.

Jacobs L., Emerson S. and Huested S. (1987) Trace metal geochemistry in the Cariaco Trench. Deep Sea Res. 34(5), 965-981.

Jacobs L., Emerson S. and Skei J. (1985) Partitioning and transport of metals across the $\mathrm{O}_{2}$ $\mathrm{H}_{2} \mathrm{~S}$ interface in a permanently anoxic basin: Framvaren Fjord, Norway. Geochim. Cosmochim. Acta 49(6), 1433-1444.

Jacquot, J. E., and Moffett, J. W. (2015). Copper distribution and speciation across the International GEOTRACES Section GA03. Deep Sea Res. Pt II 116, 187-207.

Jeandel, C., Arsouze, T., Lacan, F., Techine, P., and Dutay, J. C. (2007). Isotopic Nd compositions and concentrations of the lithogenic inputs into the ocean: A compilation, with an emphasis on the margins. Chem. Geol. 239(1), 156-164.

Jickells T., An Z., Andersen K. K., Baker A., Bergametti G., Brooks N., Cao J., Boyd P., Duce R. and Hunter K., et al. (2005) Global iron connections between desert dust, ocean biogeochemistry, and climate. Science 308(5718), 67-71.

Johnson, K., Purvis, G., Lopez-Capel, E., Peacock, C., Gray, N., Wagner, T., ... and Robertson, S. (2015). Towards a mechanistic understanding of carbon stabilization in manganese oxides. Nat. Commun. 6, 7628.

Jones, M. T., Pearce, C. R., Jeandel, C., Gislason, S. R., Eiriksdottir, E. S., Mavromatis, V., and Oelkers, E. H. (2012). Riverine particulate material dissolution as a significant flux of strontium to the oceans. Earth Planet. Sci. Lett. 355, 51-59. 
Jones, M. T., Gislason, S. R., Burton, K. W., Pearce, C. R., Mavromatis, V., von Strandmann, P. A. P., and Oelkers, E. H. (2014). Quantifying the impact of riverine particulate dissolution in seawater on ocean chemistry. Earth Planet. Sci. Lett. 395, 91-100.

Keeling, R. F., Körtzinger, A., and Gruber, N. (2010). Ocean deoxygenation in a warming world. Marine Science 2.

Klinkhammer, G. P. (1980). Early diagenesis in sediments from the eastern equatorial Pacific, II. Pore water metal results. Earth Planet. Sci. Lett. 49(1), 81-101.

Kuwabara, J. S., Topping, B. R., Coale, K. H., and Berelson, W. M. (1999). Processes affecting the benthic flux of trace metals into the water column of San Francisco Bay. In US Geological Survey Toxic Substances Hydrology Program--Proceedings of the Technical Meeting, Charleston, South Carolina 2, 115-119.

Laglera, L. M., and van den Berg, C. M. (2003). Copper complexation by thiol compounds in estuarine waters. Mar. Chem. 82(1), 71-89.

Lalonde, K., Mucci, A., Ouellet, A., and Gélinas, Y. (2012). Preservation of organic matter in sediments promoted by iron. Nature 483(7388), 198-200.

Leal, M. F. C., and Van Den Berg, C. M. (1998). Evidence for strong copper (I) complexation by organic ligands in seawater. Aquat. Geochem. 4(1), 49-75.

Li, C., Love, G. D., Lyons, T. W., Fike, D. A., Sessions, A. L., and Chu, X. (2010a). A stratified redox model for the Ediacaran ocean. Science 328(5974), 80-83.

Li, X., Gilhooly, W. P., III, Zerkle, A. L., Lyons, T. W., Farquhar, J., Werne, J. P., Varela, R., and Scranton, M. L. (2010b) Stable sulfur isotopes in the water column of the Cariaco Basin. Geochim. Cosmochim. Acta 74(23), 6764-6778.

Li, X., Cutter, G. A., Thunell, R. C., Tappa, E., Gilhooly, W. P., III, Lyons, T. W., Astor, Y., and Scranton, M. I. (2011) Particulate sulfur species in the water column of the Cariaco Basin. Geochim. Cosmochim. Acta 75(1), 148-163.

Little, S. H., Vance, D., Walker-Brown, C., and Landing, W. M. (2014a) The oceanic mass balance of copper and zinc isotopes, investigated by analysis of their inputs, and outputs to ferromanganese oxide sediments. Geochim. Cosmochim. Acta 125, 673693.

Little, S. H., Sherman, D. M., Vance, D., and Hein, J. R. (2014b). Molecular controls on $\mathrm{Cu}$ and $\mathrm{Zn}$ isotopic fractionation in Fe-Mn crusts. Earth Planet. Sci. Lett. 396, 213222.

Little, S. H., Vance, D., Lyons, T. W., and McManus, J. (2015). Controls on trace metal authigenic enrichment in reducing sediments: Insights from modern oxygen-deficient settings. Am. J. Sci. 315(2), 77-119.

Little, S. H., Vance, D., McManus, J., and Severmann, S. (2016). Key role of continental margin sediments in the oceanic mass balance of $\mathrm{Zn}$ and $\mathrm{Zn}$ isotopes. Geology 44(3), $207-210$.

Lucia, M., Campos, A. M., and van den Berg, C. M. (1994). Determination of copper complexation in sea water by cathodic stripping voltammetry and ligand competition with salicylaldoxime. Anal. Chim. Acta 284(3), 481-496. 
Lückge, A., and Reinhardt, L. (2000) CTD measurements in the water column off Peru, in Kudrass, H. R., editor, Cruise report SO147 Peru Upwelling: Valparaiso-Callao, 29.05-03.07, 35-37.

Lyons, T. W. (1991) Upper Holocene sediments of the Black Sea: Summary of Leg 4 box cores (1988 Black Sea oceanographic expedition), in Izdar, E., and Murray, J. W., editors, Black Sea Oceanography. NATO ASI Series 351, 401-441.

Lyons, T. W. (1997) Sulfur isotopic trends and pathways of iron sulfide formation in upper Holocene sediments of the anoxic Black Sea. Geochim. Cosmochim. Acta 61(16), 3367-3382.

Lyons, T. W., and Berner, R. A. (1992) Carbon-sulfur-iron systematics of the uppermost deep-water sediments of the Black Sea. Chem. Geol. 99(1-3), 1-27.

Lyons, T. W., and Severmann, S. (2006) A critical look at iron paleoredox proxies: New insights from modern euxinic marine basins. Geochim. Cosmochim. Acta 70(23), 5698-5722.

Lyons, T. W., Berner, R. A., and Anderson, R. F. (1993) Evidence for large pre-industrial perturbations of the Black Sea chemocline. Nature 365, p. 538-540,

Lyons, T. W., Werne, J. P., Hollander, D. J., and Murray, R. W. (2003) Contrasting sulfur geochemistry and $\mathrm{Fe} / \mathrm{Al}$ and $\mathrm{Mo} / \mathrm{Al}$ ratios across the last oxic-to-anoxic transition in the Cariaco Basin, Venezuela. Chem. Geol. 195(1-4), 131-157.

Lyons, T. W., Reinhard, C., and Planavsky, N. (2014) The rise of oxygen in Earth's early ocean and atmosphere. Nature 506, 307-315.

Macías, D., Franks, P. J., Ohman, M. D., and Landry, M. R. (2012). Modeling the effects of coastal wind-and wind-stress curl-driven upwellings on plankton dynamics in the Southern California current system. J. Marine Sys. 94, 107-119.

Malouta, D. N., Gorsline, D. S., and Thornton, S. E. (1981). Processes and rates of recent (Holocene) basin filling in an active transform margin: Santa Monica Basin, California Continental Borderland. J. Sed. Res. 51(4).

Maréchal C. N., Telouk P. and Albarède F. (1999) Precise analysis of copper and zinc isotopic compositions by plasma-source mass spectrometry. Chem. Geol. 156(1-4), 251-273.

Martinez, N. C., Murray, R. W., Thunell, R. C., Peterson, L. C., Muller-Karger, F., Lorenzoni, L., ... and Varela, R. (2010). Local and regional geochemical signatures of surface sediments from the Cariaco Basin and Orinoco Delta, Venezuela. Geology 38(2), 159-162.

Mathur, R., Titley, S., Barra, F., Brantley, S., Wilson, M., Phillips, A., ... and Hart, G. (2009). Exploration potential of $\mathrm{Cu}$ isotope fractionation in porphyry copper deposits. J. Geochem. Explor. 102(1), 1-6.

Martin, J. M., and Meybeck, M. (1979). Elemental mass-balance of material carried by major world rivers. Mar. Chem. 7(3), 173-206.

McManus, J., Berelson, W. M., Coale, K. H., Johnson, K. S., and Kilgore, T. E. (1997). Phosphorus regeneration in continental margin sediments. Geochim. Cosmochim. Acta 61(14), 2891-2907.

McManus, J., Berelson, W. M., Klinkhammer, G. P., Johnson, K. S., Coale, K. H., Anderson, R. F., ... and McCorkle, D. C. (1998). Geochemistry of barium in marine 
sediments: Implications for its use as a paleoproxy. Geochim. Cosmochim. Acta 62(21), 3453-3473.

McManus J., Berelson W., Severmann S., Poulson R., Hammond D., Klinkhammer G. and Holm C. (2006) Molybdenum and uranium geochemistry in continental margin sediments: paleoproxy potential. Geochim. Cosmochim. Acta 70(18), 4643-4662.

Moffett J. W. and Brand L. E. (1996) Production of strong, extracellular Cu chelators by

Moffett J. W. and Dupont C. (2007) Cu complexation by organic ligands in the sub-arctic NW Pacific and Bering Sea. Deep Sea Res. Pt I 54(4), 586-595.

Moffett, J. W., Zika, R. G., and Brand, L. E. (1990). Distribution and potential sources and sinks of copper chelators in the Sargasso Sea. Deep Sea Res. 37(1), 27-36.

Morford, J. L., and Emerson, S. (1999). The geochemistry of redox sensitive trace metals in sediments. Geochim. Cosmochim. Acta 63(11), 1735-1750.

Morris, A. W., Mantoura, R. F. C., Bale, A. J., and Howland, R. J. M. (1978). Very low salinity regions of estuaries: important sites for chemical and biological reactions. Nature 274(5672), 678-680.

Moynier, F., Vance, D., Fujii, T., Savage, P. (in press) The Isotope Geochemistry of Zinc and Copper. Rev. Mineral. Geochem. 82.

Muller, F. L. L., Gulin, S. B., and Kalvøy, A. (2001) Chemical speciation of copper and zinc in surface waters of the western Black Sea. Mar. Chem. 76(4), 233-251.

Muñoz, P., Lange, C. B., Gutiérrez, D., Hebbeln, D., Salamanca, M. A., Dezileau, L., ... and Benninger, L. K. (2004). Recent sedimentation and mass accumulation rates based on $210 \mathrm{~Pb}$ along the Peru-Chile continental margin. Deep Sea Res. Pt II 51(20), 25232541.

Murray, J. W., Jannasch, H. W., Honjo, S., Anderson, R. F., Reeburgh, W. S., Top, Z., Friederich, G. E., Codispoti, L. A., and Izdar, E. (1989) Unexpected changes in the oxic/anoxic interface in the Black Sea. Nature 338, 411-413

Murray, J. W., Top, Z., and Özsoy, E. (1991). Hydrographic properties and ventilation of the Black Sea. Deep Sea Res. 38, S663-S689.

Nägler T., Neubert N., Böttcher M., Dellwig O. and Schnetger B. (2011) Molybdenum isotope fractionation in pelagic euxinia: evidence from the modern Black and Baltic Seas. Chem. Geol. 289(1), 1-11.

Neubert, N., Nägler, T. F., and Böttcher, M. E. (2008). Sulfidity controls molybdenum isotope fractionation into euxinic sediments: Evidence from the modern Black Sea. Geology 36(10), 775-778.

Nielsen, S. G., Rehkämper, M., Teagle, D. A., Butterfield, D. A., Alt, J. C., and Halliday, A. N. (2006). Hydrothermal fluid fluxes calculated from the isotopic mass balance of thallium in the ocean crust. Earth Planet. Sci. Lett. 251(1), 120-133.

Noffke, A., Hensen, C., Sommer, S., Scholz, F., Bohlen, L., Mosch, T., Graco, M., and Wallman, K. (2012) Benthic iron and phosphorus fluxes across the Peruvian oxygen minimum zone. Limnol. Oceanogr. 57(3), 851-867.

Oelkers, E. H., Jones, M. T., Pearce, C. R., Jeandel, C., Eiriksdottir, E. S., and Gislason, S. R. (2012). Riverine particulate material dissolution in seawater and its implications for the global cycles of the elements. C. R. Geosci. 344(11), 646-651. 
Östlund, H.G. (1974). Expedition "Odysseus 65": Radiocarbon age of Black Sea deep water. In The Black Sea-Geology, chemistry, and biology (eds. E.T. Degens and D.A. Ross). American Association of Petroleum Geologists Memoir 20, 127-132.

Özsoy, E., and Ünlüata, Ü. (1997). Oceanography of the Black Sea: a review of some recent results. Earth-Sci. Rev. 42(4), 231-272.

Peacock, C. L., and Moon, E. M. (2012). Oxidative scavenging of thallium by birnessite: explanation for thallium enrichment and stable isotope fractionation in marine ferromanganese precipitates. Geochim. Cosmochim. Acta 84, 297-313.

Pearce, C. R., Jones, M. T., Oelkers, E. H., Pradoux, C., and Jeandel, C. (2013). The effect of particulate dissolution on the neodymium $(\mathrm{Nd})$ isotope and Rare Earth Element (REE) composition of seawater. Earth Planet. Sci. Lett. 369, 138-147.

Peterson, L. C, Haug, G. H., Murray, R. W., Yarincik, K. M., King, J. W., Bralower, T. J., Kameo, K., Rutherford, S. D., and Pearce, R. B. (2000) Late Quaternary stratigraphy and sedimentation at Site 1002, Cariaco Basin (Venezuela). Proc. ODP - Scientific Results 165, 85-99.

Poulson-Brucker R., McManus J., Severmann S. and Berelson W. (2009) Molybdenum behavior during early diagenesis: insights from Mo isotopes. Geochem. Geophys. Geosyst. 10(6), Q06010.

Prospero, J. M. (1996). Saharan dust transport over the North Atlantic Ocean and Mediterranean: an overview. In The impact of desert dust across the Mediterranean (eds. S. Guerzoni and R. Chester). Springer, Netherlands. pp. 133-151.

Reinhard, C. T., Planavsky, N. J., Wang, X., Fischer, W. W., Johnson, T. M., and Lyons, T. W. (2014) The isotopic composition of authigenic chromium in anoxic marine sediments: A case study from the Cariaco Basin. Earth Planet. Sci. Lett. 407, 9-18.

Resing, J. A., Sedwick, P. N., German, C. R., Jenkins, W. J., Moffett, J. W., Sohst, B. M., and Tagliabue, A. (2015). Basin-scale transport of hydrothermal dissolved metals across the South Pacific Ocean. Nature 523(7559), 200-203.

Roshan, S., and Wu, J. (2015). The distribution of dissolved copper in the tropicalsubtropical north Atlantic across the GEOTRACES GA03 transect. Mar. Chem. 176, 189-198.

Roshan, S., Wu, J., and Jenkins, W. J. (2016). Long-range transport of hydrothermal dissolved $\mathrm{Zn}$ in the tropical South Pacific. Mar. Chem. 183, 25-32.

Rudnick R. and Gao S. (2003) Composition of the continental crust. Treatise Geochem. 3, $1-64$.

Ryan, B. M., Kirby, J. K., Degryse, F., Scheiderich, K., and McLaughlin, M. J. (2014). Copper isotope fractionation during equilibration with natural and synthetic ligands. Environ. Sci. Technol. 48(15), 8620-8626.

Saager, P. M., De Baar, H. J., \& Howland, R. J. (1992). Cd, Zn, Ni and Cu in the Indian Ocean. Deep Sea Res. 39(1), 9-35.

Saager, P. M., Schijf, J., and de Baar, H. J. (1993). Trace-metal distributions in seawater and anoxic brines in the eastern Mediterranean Sea. Geochim. Cosmochim. Acta 57(7), 1419-1432.

Sander, S. G., and Koschinsky, A. (2011). Metal flux from hydrothermal vents increased by organic complexation. Nat. Geosci. 4(3), 145-150. 
Sansone, F. J., Graham, A. W., and Berelson, W. M. (2004). Methane along the western Mexican margin. Limnol. Oceanogr. 49(6), 2242-2255.

Sarbas, B., and Nohl, U. (2009) The GEOROC database - a decade of "online Geochemistry". Geochim. Cosmochim. Acta 73(13) Supplement, A1158.

Sawlan, J. J., and Murray, J. W. (1983). Trace metal remobilization in the interstitial waters of red clay and hemipelagic marine sediments. Earth Planet. Sci. Lett. 64(2), 213-230.

Schlitzer., R. (2015) Ocean Data View, odv.awi.de

Schmitt, A. D., Chabaux, F., and Stille, P. (2003). The calcium riverine and hydrothermal isotopic fluxes and the oceanic calcium mass balance. Earth Planet. Sci. Lett. 213(3), 503-518.

Scholz, F., Hensen, C., Noffke, A., Rohde, A., Liebetrau, V., and Wallmann, K. (2011) Early diagenesis of redox-sensitive trace metals in the Peru upwelling area - response to ENSO-related oxygen fluctuations in the water column. Geochim. Cosmochim. Acta 75(22), 7257-7276.

Scholz, F., McManus, J., and and Sommer, S. (2013) The manganese and iron shuttle in a modern euxinic basin and implications for molybdenum cycling at euxinic ocean margins. Chem. Geol. 355, 56-68.

Scholz, F., Severmann, S., McManus, J., and Hensen, C. (2014) Beyond the Black Sea paradigm: The sedimentary fingerprint of an open-marine iron shuttle. Geochim. Cosmochim. Acta 127, 368-380.

Schunck, H., Lavik, G., Desai, D. K., Grøkopf, T., Kalvelage, T., Löscher, C. R., Paulmier, A., Contreras, S., Siegel, H., Holtappels, M., Rosenstiel, P., Schilhabel, M. B., Graco, M., Schmitz, R. A., Kuypers, M. M. M., and LaRoche, J. (2013) Giant Hydrogen Sulfide Plume in the Oxygen Minimum Zone off Peru Supports Chemolithoautotrophy. PLOS ONE 8(8), e68661.

Schwalbach, J. R., and Gorsline, D. S. (1985). Holocene sediment budgets for the basins of the California continental borderland. J. Sed. Res. 55(6).

Severmann, S., Lyons, T. W., Anbar, A., McManus, J., and Gordon, G. (2008) Modern iron isotope perspective on the benthic iron shuttle and the redox evolution of ancient oceans. Geology 36(6), 487-490.

Severmann, S., McManus, J., Berelson, W. M., and Hammond, D. E. (2010). The continental shelf benthic iron flux and its isotope composition. Geochim. Cosmochim. Acta 74(14), 3984-4004.

Shank, G. C., Skrabal, S. A., Whitehead, R. F., and Kieber, R. J. (2004a). Strong copper complexation in an organic-rich estuary: the importance of allochthonous dissolved organic matter. Mar. Chem. 88(1), 21-39.

Shank, G. C., Skrabal, S. A., Whitehead, R. F., Avery, G. B., and Kieber, R. J. (2004b). River discharge of strong $\mathrm{Cu}$-complexing ligands to South Atlantic Bight waters. Mar. Chem. 88(1), 41-51.

Shaw, T. J., Gieskes, J. M., and Jahnke, R. A. (1990) Early diagenesis in differing depositional environments: The response of transition metals in pore water. Geochim. Cosmochim. Acta 54(5), 1233-1246. 
Sherman, D. M. (2013). Equilibrium isotopic fractionation of copper during oxidation/reduction, aqueous complexation and ore-forming processes: Predictions from hybrid density functional theory. Geochim. Cosmochim. Acta 118, 85-97.

Sholkovitz, E. R., P. N. Sedwick, and T. M. Church (2010). On the fractional solubility of copper in marine aerosols: Toxicity of aeolian copper revisited, Geophys. Res. Lett. 37, L20601, doi:10.1029/2010GL044817 .

Silverberg, N., Martínez, A., Aguíñiga, S., Carriquiry, J. D., Romero, N., Shumilin, E., and Cota, S. (2004). Contrasts in sedimentation flux below the southern California Current in late 1996 and during the El Niño event of 1997-1998. Estuar. Coast. Shelf Sci. 59(4), 575-587.

Skrabal, S. A., Donat, J. R., and Burdige, D. J. (1997). Fluxes of copper-complexing ligands from estuarine sediments. Limnol. Oceanogr. 42(5), 992-996.

Skrabal, S. A., Donat, J. R., and Burdige, D. J. (2000). Pore water distributions of dissolved copper and copper-complexing ligands in estuarine and coastal marine sediments. Geochim. Cosmochim. Acta 64(11), 1843-1857.

Smith, R. W., Bianchi, T. S., Allison, M., Savage, C., and Galy, V. (2015). High rates of organic carbon burial in fjord sediments globally. Nat. Geosci. 8(6), 450-453.

Stott, L. D., Berelson, W., Douglas, R., and Gorsline, D. (2000). Increased dissolved oxygen in Pacific intermediate waters due to lower rates of carbon oxidation in sediments. Nature 407(6802), 367-370.

Stramma, L., Johnson, G. C., Sprintall, J., and Mohrholz, V. (2008). Expanding oxygenminimum zones in the tropical oceans. Science 320(5876), 655-658.

Takano, S., Tanimizu, M., Hirata, T., and Sohrin, Y. (2014). Isotopic constraints on biogeochemical cycling of copper in the ocean. Nat. commun. 5, 5663.

Tankéré S. P. C., Muller F. L. L., Burton J. D., Statham P. J., Guieu C. and Martin J. M. (2001) Trace metal distributions in shelf waters of the northwestern black sea. Cont. Shelf Res. 21(13-14), 1501-1532.

Taylor S. and McLennan S. (1985). The continental crust: its composition and evolution.

Thompson, C. M., and Ellwood, M. J. (2014). Dissolved copper isotope biogeochemistry in the Tasman Sea, SW Pacific Ocean. Mar. Chem. 165, 1-9.

Thunell, R. C., Tappa, E., and Anderson, D. M. (1995). Sediment fluxes and varve formation in Santa Barbara Basin, offshore California. Geology 23(12), 1083-1086.

Thunell, R. C., Varela, R., Llano, M., Collister, J., Karger, F. M., and Bohrer, R. (2000). Organic carbon fluxes, degradation, and accumulation in an anoxic basin: sediment trap results from the Cariaco Basin. Limnol. Oceanogr. 45(2), 300-308.

Tipper E., Gaillardet J., Galy A., Louvat P., Bickle M. and Capmas F. (2010) Calcium isotope ratios in the world's largest rivers: a constraint on the maximum imbalance of oceanic calcium fluxes. Global Biogeochem. Cycles 24(3).

Tipper E., Galy A., Gaillardet J., Bickle M., Elderfield H. and Carder E. (2006) The magnesium isotope budget of the modern ocean: constraints from riverine magnesium isotope ratios. Earth Planet. Sci. Lett. 250(1), 241-253.

Tribovillard, N., Hatem, E., Averbuch, O., Barbecot, F., Bout-Roumazeilles, V., and Trentesaux, A. (2015). Iron availability as a dominant control on the primary 
composition and diagenetic overprint of organic-matter-rich rocks. Chem. Geol. 401, $67-82$.

Trocine R. P. and Trefry J. H. (1988) Distribution and chemistry of suspended particles from an active hydrothermal vent site on the Mid-Atlantic Ridge at 26 N. Earth Planet. Sci. Lett. 88(1-2), 1-15.

Vance D., Archer C., Bermin J., Perkins J., Statham P. J., Lohan M. C., Ellwood M. J. and Mills R. A. (2008) The copper isotope geochemistry of rivers and the oceans. Earth Planet. Sci. Lett. 274(1-2), 204-213.

Vance, D., Little, S. H., Archer, C., Cameron, V., Andersen, M. B., Rijkenberg, M. J., and Lyons, T. W. (2016a). The oceanic budgets of nickel and zinc isotopes: the importance of sulfidic environments as illustrated by the Black Sea. Phil. Trans. R. Soc. A, 374(2081), 20150294.

Vance, D., Matthews, A., Keech, A., Archer, C., Hudson, G., Pett-Ridge, J., and Chadwick, O. A. (2016b). The behaviour of $\mathrm{Cu}$ and $\mathrm{Zn}$ isotopes during soil development: Controls on the dissolved load of rivers. Chem. Geol. 445, 36-53.

van Geen, A., Zheng, Y., Bernhard, J. M., Cannariato, K. G., Carriquiry, J., Dean, W. E., ... and Pike, J. (2003). On the preservation of laminated sediments along the western margin of North America. Paleoceanography 18(4).

Wasylenki, L. E., Weeks, C. L., Bargar, J. R., Spiro, T. G., Hein, J. R., and Anbar, A. D. (2011). The molecular mechanism of Mo isotope fractionation during adsorption to birnessite. Geochim. Cosmochim. Acta 75(17), 5019-5031.

Welch, S. A., Beard, B. L., Johnson, C. M., and Braterman, P. S. (2003). Kinetic and equilibrium $\mathrm{Fe}$ isotope fractionation between aqueous $\mathrm{Fe}$ (II) and $\mathrm{Fe}$ (III). Geochim. Cosmochim. Acta 67(22), 4231-4250.

Wells, M. L., Kozelka, P. B., and Bruland, K. W. (1998). The complexation of dissolved $\mathrm{Cu}, \mathrm{Zn}, \mathrm{Cd}$ and $\mathrm{Pb}$ by soluble and colloidal organic matter in Narragansett Bay, RI. Mar. Chem. 62(3), 203-217.

Werne, J. P., Lyons, T. W., Hollander, D. J., Formolo, M. J., and Sinninghe Damsté, J. S. (2003) Reduced sulfur in euxinic sediments of the Cariaco Basin: sulfur isotope constraints on organic sulfur formation. Chem. Geol. 195(1-4), 159-179.

Windom, H., Wallace, G., Smith, R., Dudek, N., Maeda, M., Dulmage, R., and Storti, F. (1983). Behavior of copper in southeastern United States estuaries. Mar. Chem. 12(23), 183-193.

Xue, Z., Rehkämper, M., Horner, T. J., Abouchami, W., Middag, R., van de Flierdt, T., and de Baar, H. J. (2013). Cadmium isotope variations in the Southern Ocean. Earth Planet. Sci. Lett. 382, 161-172.

Yarincik, K. M., Murray, R. W., and Peterson, L. C. (2000). Climatically sensitive eolian and hemipelagic deposition in the Cariaco Basin, Venezuela, over the past 578,000 years: Results from Al/Ti and K/Al. Paleoceanography 15(2), 210-228.

Zheng, Y., Anderson, R. F., van Geen, A., and Kuwabara, J. (2000). Authigenic molybdenum formation in marine sediments: a link to pore water sulfide in the Santa Barbara Basin. Geochim. Cosmochim. Acta 64(24), 4165-4178.

Zhu, P., and Macdougall, J. D. (1998). Calcium isotopes in the marine environment and the oceanic calcium cycle. Geochim. Cosmochim. Acta 62(10), 1691-1698. 
Zhu, X. K., Guo, Y., Williams, R. J. P., O’nions, R. K., Matthews, A., Belshaw, N. S., ... and Salvato, B. (2002). Mass fractionation processes of transition metal isotopes.

1385 Earth Planet. Sci. Lett. 200(1), 47-62. 